\title{
A Conceptual and Systematics for Intelligent Power Management System-Based Cloud Computing: Prospects, and Challenges
}

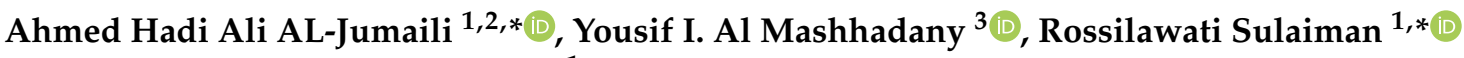 \\ and Zaid Abdi Alkareem Alyasseri ${ }^{1}$ \\ 1 Faculty of Information Science and Technology, Universiti Kebangsaan Malaysia, Bangi 43600, Malaysia; \\ zaid.alyasseri@ukm.edu.my \\ 2 Computer Centre Department, University of Fallujah, Anbar 00964, Iraq \\ 3 Department of Electrical Engineering, College of Engineering, University of Anbar, Anbar 00964, Iraq; \\ yousif.mohammed@uoanbar.edu.iq \\ * Correspondence: ahmed_hadi@uofallujah.edu.iq (A.H.A.A.J.); rossilawati@ukm.edu.my (R.S.)
}

Citation: AL-Jumaili, A.H.A.; Mashhadany, Y.I.A.; Sulaiman, R.; Alyasseri, Z.A.A. A Conceptual and Systematics for Intelligent Power Management System-Based Cloud Computing: Prospects, and Challenges. Appl. Sci. 2021, 11, 9820 https://doi.org/10.3390/app11219820

Academic Editors: Paula

Fraga-Lamas, Tiago M.

Fernández-Caramés and

Sérgio Ivan Lopes

Received: 16 August 2021

Accepted: 8 October 2021

Published: 20 October 2021

Publisher's Note: MDPI stays neutral with regard to jurisdictional claims in published maps and institutional affiliations.

Copyright: (c) 2021 by the authors. Licensee MDPI, Basel, Switzerland. This article is an open access article distributed under the terms and conditions of the Creative Commons Attribution (CC BY) license (https:// creativecommons.org/licenses/by/ $4.0 /)$.

\begin{abstract}
This review describes a cloud-based intelligent power management system that uses analytics as a control signal and processes balance achievement pointer, and describes operator acknowledgments that must be shared quickly, accurately, and safely. The current study aims to introduce a conceptual and systematic structure with three main components: demand power (direct current (DC)-device), power mix between renewable energy (RE) and other power sources, and a cloud-based power optimization intelligent system. These methods and techniques monitor demand power (DC-device), load, and power mix between RE and other power sources. Cloud-based power optimization intelligent systems lead to an optimal power distribution solution that reduces power consumption or costs. Data has been collected from reliable sources such as Science Direct, IEEE Xplore, Scopus, Web of Science, Google Scholar, and PubMed. The overall findings of these studies are visually explained in the proposed conceptual framework through the literature that are considered to be cloud computing based on storing and running the intelligent systems of power management and mixing.
\end{abstract}

Keywords: power management; state of charge; battery aging; dc-device; power consumption; renewable energy; cloud computing

\section{Introduction}

In the last decade of industrial progress, the world economy has shifted from cheap energy to expensive fuel consumption. However, industrialization necessitates an increasing amount of energy, which is a condition for humanity's economic prosperity and sustainability [1]. Awareness of the relative constraints of traditional energy resource exhaustion is essential; however, the restricted energy supply from RE sources is necessary. Thus, these two factors have not only a two-fold influence on energy and economic development only, but also on the environment. A cyber-physical system in which electrical components are controlled by a computer and connected to a network of other computer-controlled physical equipment is known as a power grid [2]. The power grid includes the movement of electricity and information between the power grid and control centers [3]. Safe and reliable grid operation requires controlling the energy flow such that the supply and demand can be well balanced in real-time [4]. It is necessary to ensure that information flows as intended as any disruption in information flow will affect the correct conduct of energy flow and the system's safe and dependable functioning [5,6]. In traditional power networks, the supply and demand balancing are generally achieved by adjusting the output of centralized generating units [5]. When consumption rises, the production must increase to keep up. Similarly, as demand falls, the created production must be reduced [7]. 
The power system has witnessed significant modifications in recent years due to the rapid growth of a distributed generation (DG). DG, unlike centralized generators, are mostly weather-dependent and hence have limited controllability to meet demand. Due to their various sizes and network tiers to which they are attached, they also add more unpredictability to the entire operation [8]. Recent environmental worries about growing carbon dioxide emissions (CDE), expanding energy needs, and the liberalization of the electrical industry have drawn the world's attention to renewable energy technology [9]. Although the integration of intermittent RE generation into electrical power systems is still relatively new in the evolution of electrical systems, it is popular all over the world due to its technical advantages such as improved voltage profile, power quality (PQ), voltage stability, reliability and grid support [8]. According to the modern grid initiative study from the United States Department of Energy (USDOE), a modern smart grid (SG) must be capable of self-healing and distributing high-quality power in order to avoid wasting money due to outages [9].

This study focuses on the uses of a variety of RE sources, including unlimited and other power sources. Moreover, it focuses on conserving energy and spending it wisely following its direction and location. Furthermore, reducing costs by using suitable energy sources depends on prioritizing using a multi-heuristic technique for intelligent power systems. All these processes and data will be saves and controlled by a cloud computing framework using a cloud sim. Cloud computing can be a great addition to any system aiming for an optimal solution for power distribution to reduce cost and waste power and time.

\subsection{Smart Energy Systems}

Societies on a global scale have reached a tipping point from fossil fuel power generation to sustainable alternatives. However, wireless connectivity plays a critical role in this transformation by enabling innovative smart energy systems (SESs) [9]. SES is a novel solution, which integrates energy generating and storage technologies with 'intelligent' applications, regulating and optimizing their usage. Cloud computing can use combined multiple energy sources with storage systems to manage them [10]. Furthermore, significant points to improve SES require real-time performance decisions based on technical features and climatic data, surplus renewable power generation, and building decentralized energy systems with excellent efficiency and lower cost [11]. In addition, to reduce rising environmental hazards such as increasing global mean temperature and greenhouse gas emissions, energy systems are experiencing a rapid transition toward low-carbon intelligent systems [12]. Unlike traditional energy systems, which dispatch various generators to meet changing demand, future energy systems include two-way energy flows between providers and consumers and active engagement of customers as prosumers in various electrical markets [13]. Under the suggested micro-market, not completely controllable loads were rescheduled by changing specific lectures, research timelines and optimization by a self-crossover genetic algorithm (GA) [14]. The numerical findings revealed that the suggested micro-market and algorithm efficiently increased load flexibility and resulted in increased cost savings for intelligent energy systems [15,16], as shown in Figure 1. 


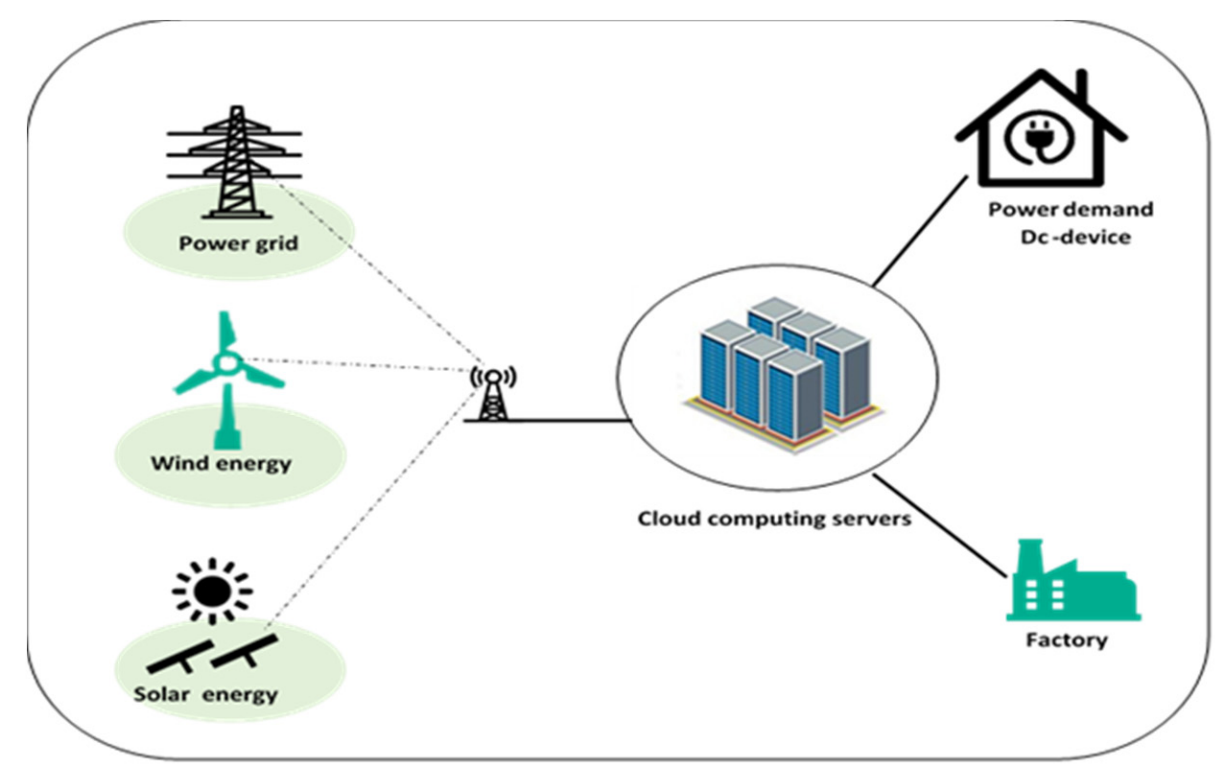

Figure 1. The schematic illustrates the smart energy system.

\subsection{Background}

The fast development of power stockpiling has received considerable attention lately [17]. The power stockpiling technique represents a popular system used in the most widely fixed and portable way [18]. Technique energy distribution consists of production, conveyance, allocation, scattered network methods, demand, administration [19]. Modern gadgets generally include many detectors to regulate and manage process variables directly. The detectors may recognize and prevent possible system faults. It is impossible to improve energy management strategies on the future route until accurate information is available [19]. As a result, the obvious visibility, high detection levels, and improved level of performance have attracted much interest. Artificial intelligence (AI) has become the focus of interest, particularly in industrial sectors, for its smart and precise natural deposit administration [20]. AI integration of fog will vastly improve the range of computing and execution speed of its base sensors in the industry [21]. However, a significant issue in using such energy-hungry gadgets, battery aging, and intolerable delays on the portable appliance is a traditional and inefficient fair distribution of precise natural trends. Demanding power management and control are critical to enhancing safety [20], reliability [17], performance, and cost [22]. Demanding power management is a choking technique due to a complicated process that is difficult to observe. Thus, it is a significant method for managing batteries to concentrate on developing a cloud-based battery for managing batteries based on an intelligent system that employs a machine-learning technique capable of operating consistently during changing environmental settings [23]. Enhanced freightage techniques are essential to later development predictions of more intelligent batteries, as the freightage efficiency has a significant impact on customer approval or rejection [24]. Technology-managing batteries on the cloud are proposed to enhance systems through enhancing arithmetic power ability, amount of data, and information stored on the internet. The internet-connected battery data is examined and analyzed and it is highly reliant on the supervision center framework for computation and connections and uses a cloud-based application server to assure procedure continuation independent of local infrastructure access and availability [21]. In addition, the growing demand for electricity worldwide, the environmental pressures, and the large-scale penetration of intermittent renewable energy sources (RESs) are compromising the operation of the electricity grid and creating new technical and economic challenges for network operators [25]. The worrying rise in power usage, natural pollution, global warming, and the exhaustion of coal and oil sources is pushing today's academics to make renewable electricity gathering easier [26]. The insertion of integrating solar panels in traditional electricity transmission lines has been 
proved fruitful [27]. However, variables such as solar irradiance, coverage of clouds, time of sunlight hours, and heat in the surroundings wreak havoc on renewable output power and total energy efficiency, which may be mitigated by combining renewable panels with energy storage devices $[28,29]$. The large penetration of solar power can cause significant voltage swings, through the use of energy storage devices. Solar power with a manageable energy storage system device also saves money for customers by reducing power consumption $[30,31]$. The collected information and data are conveyed to the cloud smoothly, which leads to creating a battery system's digital twin, as well as the battery analytical techniques that will evaluate the information and provide insight into the battery-grade level and aging $[18,32]$. To explore the advancement of information of data and connection technology, combining fossil fuels with clean power, and implementing energy management using the cloud, powered pivot, and gathered loads were used to enhance power economization in a smart society [24].

\section{Smart Grids System}

The growing energy demand has led researchers to establish a new energy management mechanism or find alternate energy resources [33]. For this purpose, the utility transforms its infrastructure into intelligent smart grids (SGs) by using bi-directional communication technologies to make wise decisions [34]. SGs mix electric power and bidirectional communication that supply the end-user with a high-performance and efficient mechanism by combining integration and communication technologies $[35,36]$. In this section, five of the major aspects will be discussed to show the best scope of these systems based on smart grid benefits, opportunities and components as depicted in Figure 2. These aspects are demand response (DR), power supply (PS), distributed energy resource (DER), microgrid trading (MT) and virtual power plants (VPPs) [37].

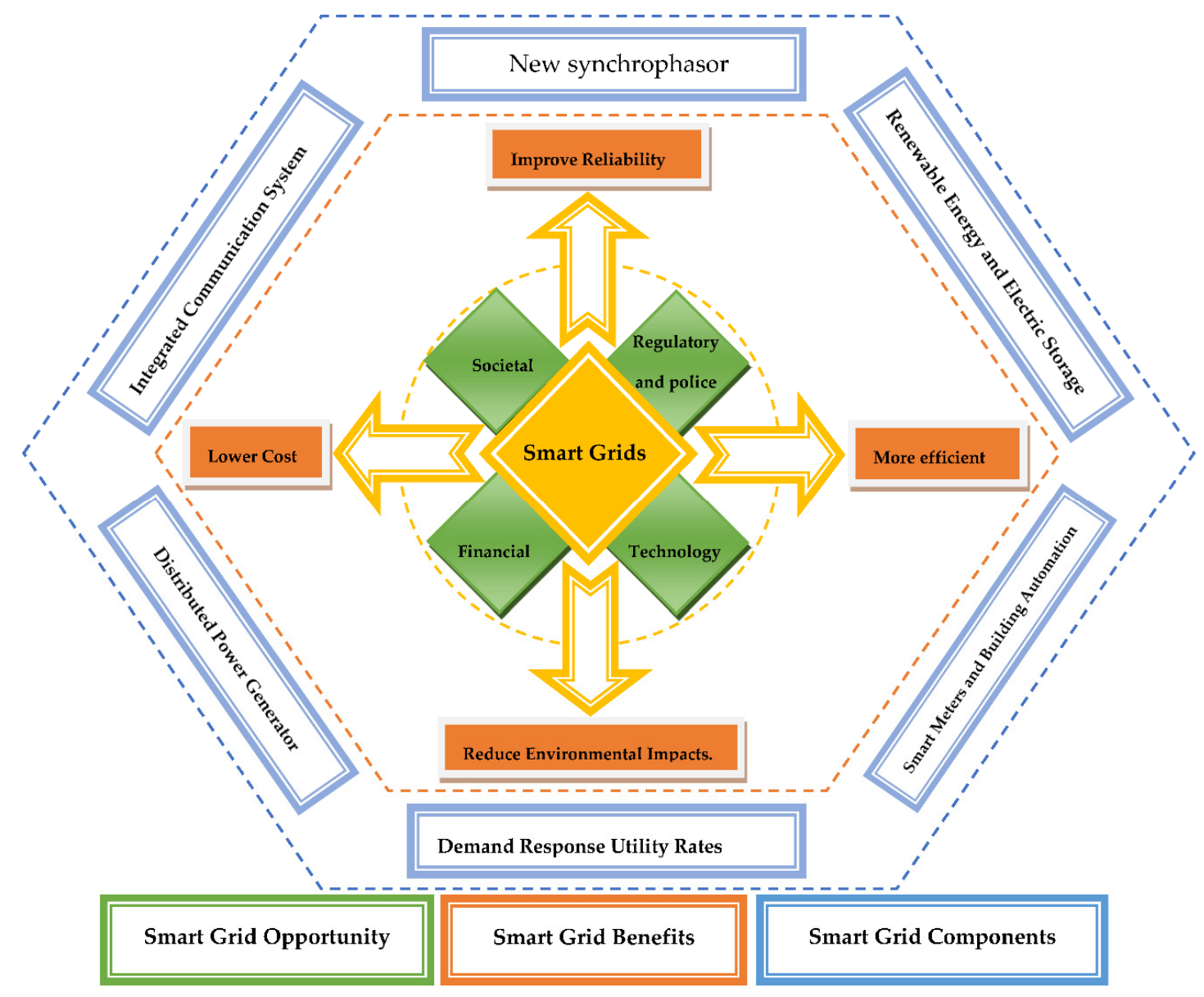

Figure 2. Smart grid opportunity, benefits, and components. 


\subsection{Demand Response (DR)}

The world's most pressing concern today is energy. As a backup generator, fossil fuels are frequently employed, although their production of $\mathrm{CO}_{2}$ affects life and the environment $[38,39]$. A novel technique called DR makes virtual generation better DR $[40,41]$. Users may program their gadgets using this approach. There are several issues with traditional smart-grid design (without the cloud) [42], which is the master-slave design that led to a risk of distributed denial of service (DDoS). However, any error may cause the entire system to fail [43]. There is a limit on how many clients may serve due to memory storage limitations, stability, and management [44]. Besides, information and data management challenges, which millions of intelligent meters necessitate for an effective method for handling massive amounts of data [45]. Cloud computing may provide a cost-effective alternative for data analytic and storage methods $[46,47]$. Recently, the high insertion of green power, the advancement and implementation of new technology such as electricity storage methods and electronics technologies, and the effective engagement of (DR) from the user aspect, the intelligent network is currently succumbing to a deep change [48]. Customers' / clients' power consuming routines are changed by DR due to the current power cost, benefit plans, and whenever the device dependability is threatened [49]. DR's elastic scheduling may be tailored to customers' economy and power use goals, that have been used over time to help business, manufacturing, and housing customers reduce their power consumption [50]. DR scheduling is classified depending on reward and cost. These two groups are intertwined, and many of their activities are customized to reach mutually beneficial objectives [51]. DR is the favored procedure of participation among clients and the electricity network in the electricity marketing development. In addition to minimizing the variance among maximum load and maximum valley, the load profile could be developed; these lead to making the device's cost cheaper, and to the system pressure being relieved to obtain more money to be invested in raising the load. DR lowers the price of their energy usage for energy users, impacting their pleasure [52]. The home load has the highest ability to profoundly alter the requirement peak load amid the weights that may successfully involve DR [53]. Users may be overseeing and administering personal electricity using DR services. Consumers are motivated to employ clean power and allocate energy-saving technologies to conserve electricity, lower personal power costs, and make money by selling their extra electricity to the system through DR programs $[54,55]$. It is essential to provide a reliable, accurate, cost-effective, and safe electricity energy. The above technological advances should be able to combine the behaviors of many participants, buyers, suppliers, and prosumers efficiently [56,57]. The demand response procedure's success in regulating supply, conservation, call for cooperation, and lowering energy costs is proven based on a prototype electrical system [58,59]. For instance, the energy information administration's last annual energy outlook study predicted that household power demand will rise in the next few years [60-62].

\subsection{Power Supply}

An electrical device transforms electricity (the proper voltage, current, and frequency) from a source to an electrical load [63]. This section describes the relationship between power and energy, and their management techniques; as seen in Equation (4) and (5). Both power and energy are defined in terms of the work that a system accomplishes. It is critical to understand the distinction between power and energy. A reduction in power consumption does not always imply a reduction in the amount of energy utilized. For example, reduce central processing units (CPU) performance by lowering voltage and frequency led to reduced power consumption. It may take longer to complete the program execution in this situation. The amount of energy consumed may not be reduced even with reducing power usage [64]. As explained in the next parts, energy consumption may decrease through implementing static power management (SPM), dynamic power management (DPM), or by combining the two solutions and services $[65,66]$. Furthermore, electricity consumption may be divided into three categories: 
First: The energy consumed via parts of the system due to leaking electricity in the supplied technique is called SPM. It is unaffected by clock rates and does not rely on use situations dictated by the device type and architecture used in the service's CPU [67].

Second: Dynamic power consumption (DPC): This type of energy usage is caused by device action and is largely influenced by clock rates, I/O traffic, and the utilization situation. DPC is caused by two factors: changed capacity and short circuit current $[68,69]$. To identify basic terms: Charge can be defined as the quantity of electricity responsible for electric phenomena in Coulombs (C). Current is defined as the passage of electric signals through a network for each component during a given period, measured in amperes (A), which is expressed in Equation (1) [70]. Voltage is the amount of effort or energy necessary to move an electric charge, measured in volts (V) and expressed in Equation (2). Power is the system's rate of work, measured in watts (W), described in Equation (3). Compute power is the element current multiplied by the element voltage, expressed in Equation (4). Energy is the entire quantity of tasks finished during a period of time, measured in watt-hours (WH), described in Equation (5).

$$
\mathrm{a}=\frac{\Delta \mathrm{c}}{\Delta \mathrm{t}}
$$

where a is ampere, $\Delta \mathrm{c}$ is change of current and $\Delta \mathrm{t}$ is change of time.

$$
\mathrm{v}=\frac{\Delta \mathrm{w}}{\Delta \mathrm{c}}
$$

where $\mathrm{v}$ is Volt and $\Delta \mathrm{w}$ is change of watt and $\Delta \mathrm{c}$ is change of current.

$$
\mathrm{p}=\frac{\Delta \mathrm{w}}{\Delta \mathrm{t}}
$$

where $\mathrm{p}$ is power, $\Delta \mathrm{w}$ is change of watt, $\Delta \mathrm{t}$ is change of time.

$$
\mathrm{P}=\frac{\Delta \mathrm{w}}{\Delta \mathrm{t}}=\frac{\Delta \mathrm{c}}{\Delta \mathrm{t}} * \frac{\Delta \mathrm{w}}{\Delta \mathrm{c}}=\mathrm{a} * \mathrm{v}
$$

via derivation and substitution of variables, $\mathrm{P}=\mathrm{a} * \mathrm{v}$

$$
\mathrm{E}=\mathrm{P} * \Delta \mathrm{t}
$$

where $\mathrm{E}$ stands for energy, $\mathrm{P}$ for power, and $\Delta \mathrm{t}$ stands for alteration of time.

\subsubsection{Battery Management}

The battery management is worked from different perspectives, such as automatically controlling the SoG and the system that maintains battery aging and health. The rest of the research society considered the authority of the power consumption and reduced the costs of PS [71]. (GA) [72], particle swarm optimization (PSO) [73], fuzzy logic (FL) [74], metaheuristic optimization algorithms (MOA) [27], etc. have all been used to preserve battery life and control the charging process, which includes charging from $20 \%$ and stopping when it reaches $95 \%$. These methods and algorithms use a mix of energy sources ranging from wind energy, fossil energy, solar energy, and RE [75,76]. However, the focus is to resolve the issues between battery control and energy supplies used during freightage (see Figure 3). 


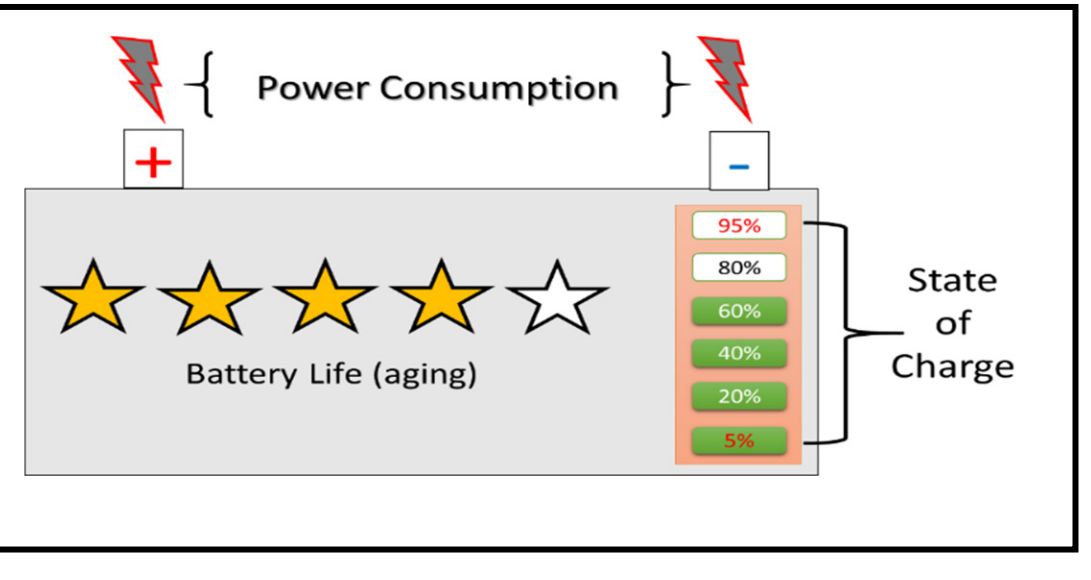

Figure 3. Power consumption control.

State of Charge (SoC)

A cell (SoC) depicts current capacity as a function of its rated capacity. The SoC's value ranges from 0 to 100 percent. The cell is fully loaded if the SoC is 100 percent, whereas an SoC of zero percent shows that the cell is entirely discharged [77]. In practical applications, the percentage or level that defines the start or end of the charging process is varied according to the charging system, whether it is manual or automatic. The beginning $\mathrm{SoC}$ is assigned as $0 \%$ and target charging SoC as $80 \%$ to compare improvements. In the same study, the optimal charging current series for $0-80 \%$ SoC with different setting time had charging times that ranged from 1 to $3 \mathrm{~h}$, with a step of $0.5 \mathrm{~h}$. Knowing the battery beginning $\mathrm{SoC}$, the target $\mathrm{SoC}$, and the charging time, it has been found that the current charging command can be easily calculated by the database-based method. Compared with the constant current charging strategy, the proposed method can effectively decrease the charging loss [72]. Furthermore, electrochemical techniques and post-mortem examination allowed the samples kept at $30 \%, 60 \%$, and $100 \%$ SoC and $55^{\circ} \mathrm{C}$ to be comprehensively examined. It was determined that the most severe capacity fading occurred when the batteries were kept at 55 degrees Celsius and $100 \%$ SoC [78]. In addition, higher stored SoC resulted in a more substantial rise in bulk resistance $\left(R_{b}\right)$ and charge-transfer resistance $\left(R_{c t}\right)$ of a full battery at $55^{\circ} \mathrm{C}$. Still, the discharge rate capability of the stored battery remained unchanged [73]. Furthermore, higher stored $\mathrm{SoC}$ resulted in a more substantial rise in bulk resistance $\left(R_{b}\right)$ and charge-transfer resistance $\left(R_{c t}\right)$ of a full battery at $55^{\circ} \mathrm{C}$. Still, the discharge rate capability of the stored battery remained unchanged [78]. However, the minimum SoC in the study never fell below $20 \%$ to avoid reducing battery life. Therefore, there was always $20 \%$ energy in the batteries in this study [73]. Factors such as charge, discharge rate, and charging/discharging hours played a significant role in correcting the load characteristic of the grid, and the islanded micro-grid was the optimal operation of energy systems [73]. The numerical simulations were used to evaluate the system's net savings for various SoC settings in the control strategy. Considering expanding data samples, the proposed approximate dynamic programming approach beat the classic dynamic programming approach [79]. The proposed approximate dynamic programming approach for microgrid power system optimization problems is a computationally efficient tool $[80,81]$ (Figure 4). 


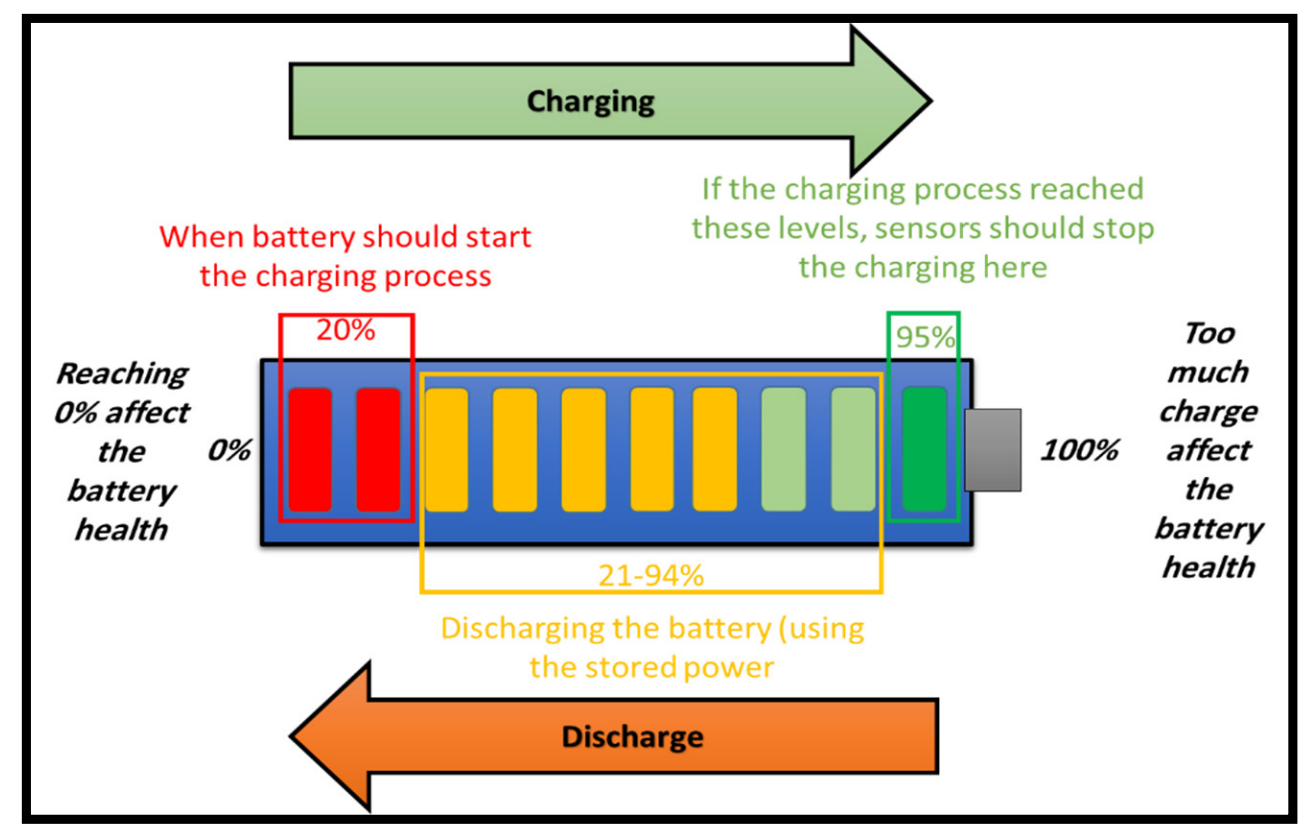

Figure 4. State of charge (SoC).

Battery Life

Determining battery aging is a crucial issue to predict the available charge in batteryoperated systems [82]. According to the literature, the batteries were charged and discharged in $5 \mathrm{~h}$ to produce a 5 kilowatt (KW) average, while the battery life was anticipated to be around ten years [73]. In comparison to the standard charging method, the results showed that the multi-stage constant current charging technique could significantly reduce charging time by $56.8 \%$, extend battery life by $21 \%$, and enhance energy efficiency by roughly 0.4 percent of constant current and constant voltage [83]. Moreover, we used four cells for experiments to ensure the consistency of the results and to reduce the effect of the cell-to-cell variations [84]. The cells were new and uncycled and stored in a thermally managed storage chamber at $10^{\circ} \mathrm{C}$ at $50 \%$ SoC before experiments to minimize their calendar aging [84]. In addition, different temperatures, charge-discharge rates, and the depth of discharge can give rise to the evolution of the dominant aging reactions that can offer guidance in selecting a reasonable factor range when designing accelerated aging tests [85]. However, the autoregressive recurrent Gaussian process regression (GPR), which considers current and historical voltage, current, and temperature measurements, as well as the prior SoC estimate, increased the estimation performance [86]. In addition, this battery management system (BMS) with FL controller method improved the battery's function and life [87].

\section{Power Consumption}

Reducing energy costs is another subject in battery management, as many researchers considered reducing power consumption in their studies. The electricity needed to operate the system is not produced by the deployed MG system [88]. Therefore, a sizing method based on the system's consumption profile and the site's weather conditions was introduced to upgrade the MG system to produce the total electricity needed by the load [89]. Moreover, they found that integration of a photovoltaic system leads to the reduced economic viability of the battery by reducing the revenues generated by the battery while performing peak shaving [89]. In addition, we proposed a scheme that creates three clusters of various objective functions to coordinate charging and discharging cycles; the first cluster uses time of use tariffs to reduce grid-integrated energy storage batteries (GIESBs) power charging costs. The second cluster uses per-unit generation from photovoltaics (PVs) and wind 
turbines (WTs) to reduce GIESBs charging power. The third cluster, however, reduces the GIE's discharge capacity [90].

\subsubsection{Renewable Energy (RE)}

Integrating RE with other power sources is considered to achieve many objectives: (1) reduce the carbon footprint; (2) reduce costs of power consumption [91]. This selection must assure user safety, efficiency, and cost savings for a given application. As a result, criteria such as power consumption, application deployment area, cable size, and line transmission losses are considered. This method was used to create a $48 \mathrm{~V} \mathrm{DC}$ bus in a small-scale laboratory system with minimal power usage [91]. Furthermore, an electric bus management system (EBMS) considers variables that may have an impact on distribution network or bus efficiency, such as the power tariff. To counteract the negative effects of opportunity charging systems, RE-based charging stations can be installed. The number of possibilities for configuring connections to be lowered during the hours of 22:00-23:00 h, encourages discussion about linked DC motor load with wind and solar power-based hybrid power systems based on a simulated outcome [92]. A battery-based energy storage system is used to control the excess power generation to maximize the utilization of these energy sources based on the required load [93]. The switching transients of renewable sources and batteries do not affect DC motor speed (load), and hence constant output power as per requirement is available. The adaptability of artificial neural networks (ANNs) allows the system to be tested in a different scenario. The controller can be trained for any change in the signal. The training accuracy is $94 \%$ [94]. It will also require city utility authorities combining novel grid elements on the Internet of RE domain in order to actualize a sustainable, transformed smart city. In the future, power business, pure renewable electricity grid structural assets, and Internet of RE technology will become increasingly valued [95]. The primary motivation for this expected paradigm shift toward renewable power grids on the Internet is to manage electricity storage [96]. The cross-cutting nature of solely renewable electricity grid architecture on the Internet of RE platforms and intelligent city elements will help shape future environmentally friendly towns [94]. Energy management systems (EMS) for various RESs target small DC grids for remote rural communities with unstable load conditions [97].The technology can be used to electrify rural settlements with the greatest possible use of RESs and storage devices. The power dissipates to the consumer through maximum RE penetration and batteries throughout the day without any divergence in the system, according to simulation and experimental investigations of the DC micro-grid with the suggested EMS [97]. Micro-grid implementation is a viable method for improving supply quality while lowering sustainable energy implementation costs.

For a hybrid micro-grid (HMG), a control scheme presents a structure for ensuring continuous PS to consumers in fifteen different modes of operation. PV, fuel cells, wind, and battery storage with configurable characteristics that were all investigated. The supervisory controller sets the reference values for the generation subsystems using the state machine approach by following a predetermined path. The discrepancy between the generated and demanded power, as well as SoC, are considered by the fuzzy controller during charging and discharging battery banks. As a result, in order to obtain the best system configuration and component sizing by defining objective functions for energy cost and power loss probability, the multi-objective particle swarm optimization (MOPSO) methodology was utilized. The modeling findings show an increase in the price of electricity, which leads to a significant increase in the use of HMG based on renewable resources. As a result, harnessing renewable resources to create electric power in India's remote places is a viable option [98]. Based on the literature, algorithms of battery management, RE, and cloud computing are summarized in Tables 1 and 2. 
Table 1. Summary of the literature algorithms of battery management, renewable energy, and cloud computing.

\begin{tabular}{|c|c|c|c|}
\hline Category & Algorithm \& Tools & Battery Categories & Ref. \\
\hline \multirow{15}{*}{ Battery Management } & $\begin{array}{l}\text { Constant current/Constant voltage } \\
(\mathrm{CC} / \mathrm{CV})\end{array}$ & $\begin{array}{l}\text { Several types of batteries, } \\
\text { Lithium-ion Battery }\end{array}$ & {$[99,100]$} \\
\hline & Arbitrage optimization algorithm & \multirow{4}{*}{$\begin{array}{l}\text { Non-Available } \\
\text { (NA) }\end{array}$} & \multirow{5}{*}[22,27,101,102]{} \\
\hline & CubeSat battery algorithm (CubeSat) & & \\
\hline & Maximum efficiency tracking (MEET) & & \\
\hline & MOA & & \\
\hline & $\begin{array}{l}\text { First access first charge (FAFC) } \\
\text { scheduling }\end{array}$ & \multirow{5}{*}{ Lithium-ion Battery } & \\
\hline & Flat feeder profile & & \multirow{4}{*}[72,103,104]{} \\
\hline & (GA) & & \\
\hline & JAYA algorithm & & \\
\hline & $\begin{array}{l}\text { Pontryagin's minimum principle } \\
\qquad(\mathrm{PMP})\end{array}$ & & \\
\hline & PSO & $\begin{array}{l}\text { Electric vehicles batteries, } \\
\text { Lithium-ion Battery }\end{array}$ & {$[28,73,75]$} \\
\hline & Orthogonal least squares algorithm & Lithium-ion Battery & [86] \\
\hline & MATLAB algorithm & Variety of batteries & [105] \\
\hline & Liquid cold plate control equation & LiFePO4 battery & [106] \\
\hline & Stochastic algorithm & Electric vehicles batteries & [107] \\
\hline \multirow{6}{*}{ Renewable energy } & (GA) & \multirow{2}{*}{ NA } & \multirow{2}{*}[108,109]{} \\
\hline & Markov decision process (MDP) & & \\
\hline & $\begin{array}{l}\text { Levenberg-Marquardt algorithm } \\
\text { (LMA) }\end{array}$ & \multirow{4}{*}{ Several of batteries } & \multirow{4}{*}{ [110] } \\
\hline & Gaussian algorithm & & \\
\hline & Forgetting factor algorithm & & \\
\hline & Trust-region reflective & & \\
\hline \multirow{5}{*}{ Cloud Computing } & BMS-Master and BMS-Slave & $\begin{array}{l}\text { Lithium-ion and } \\
\text { lead-acid batteries }\end{array}$ & [18] \\
\hline & $\begin{array}{l}\text { The home energy management } \\
\text { system (HEMS) }\end{array}$ & Electric vehicles batteries & {$[111,112]$} \\
\hline & Branch and bound algorithm & \multirow{3}{*}{ NA } & \\
\hline & $\begin{array}{c}\text { Smart home energy management } \\
\text { system (SHEMS) }\end{array}$ & & \multirow{2}{*}[113,114]{} \\
\hline & $\begin{array}{l}\text { Energy-performance trade-off multi } \\
\text { resource cloud task scheduling } \\
\text { algorithm (ETMCTSA) }\end{array}$ & & \\
\hline
\end{tabular}


Table 2. Assessment and analysis of the literature studies for battery management (BM), renewable energy (RE), and cloud computing (CC).

\begin{tabular}{|c|c|c|c|c|c|}
\hline \multirow[b]{2}{*}{ Tools/Algorithm } & \multirow[b]{2}{*}{ Achievement } & \multicolumn{3}{|c|}{ Implementation } & \multirow[b]{2}{*}{ Ref. } \\
\hline & & $\begin{array}{c}\text { BM } \\
\text { Dc-Device }\end{array}$ & RE & $\mathrm{CC}$ & \\
\hline $\begin{array}{l}\text { Constant current } \\
\text { (CC)/constant } \\
\text { voltage (CV) }\end{array}$ & $\begin{array}{l}\text { Reduce the number of battery chargers to } \\
\text { Improvements battery charging and management. }\end{array}$ & $\checkmark$ & $\times$ & $\times$ & [99] \\
\hline GA & $\begin{array}{l}\text { Propose a new charging algorithm to reducing the } \\
\text { charge energy and loss. }\end{array}$ & $\checkmark$ & $\times$ & $\times$ & {$[72]$} \\
\hline MEET algorithm & $\begin{array}{l}\text { Three types of battery energy storage systems } \\
\text { (BESSs) were used to improve the system's } \\
\text { availability and energy efficiency. }\end{array}$ & $\checkmark$ & $\times$ & $\times$ & [102] \\
\hline $\begin{array}{l}\text { Orthogonal least } \\
\text { squares algorithm }\end{array}$ & $\begin{array}{l}\text { Provide a feature stemming from (GPR) for deduces } \\
\text { the unknown SoC value's probability allocation }\end{array}$ & $\checkmark$ & $\times$ & $x$ & [86] \\
\hline Scheduling algorithm & $\begin{array}{c}\text { The numerical analysis illustrates adaptive resonant } \\
\text { beam charging (ARBC) led to } 61 \% \text { battery charging } \\
\text { energy and 53-60\% supplied power. }\end{array}$ & $\checkmark$ & $\times$ & $\times$ & {$[22]$} \\
\hline GA & $\begin{array}{c}\text { used optimum charging methods are reduced } \\
\text { charge times, performance improved, and extended } \\
\text { battery life }\end{array}$ & $\checkmark$ & $\times$ & $\times$ & [83] \\
\hline MATLAB algorithm & $\begin{array}{l}\text { The sorting and cumulative voltage summation } \\
\text { (SCVS) was shown to perform the best through the } \\
\text { solar energy option of charging the battery. }\end{array}$ & $\checkmark$ & $\times$ & $\times$ & [105] \\
\hline $\begin{array}{l}\text { PSO developed based } \\
\text { on standard IEEE } \\
\text { 69-Buses network }\end{array}$ & $\begin{array}{l}\text { A hybrid approach uses to manage the electric } \\
\text { vehicle charging station (EVCS) to peak shaving and } \\
\text { the most efficient charging/discharging of EVs } \\
\text { applied to a standard network (IEEE } 69 \text { buses). }\end{array}$ & $\checkmark$ & $\times$ & $\times$ & [73] \\
\hline PSO & $\begin{array}{l}\text { Scheduling controllers can reduce the power } \\
\text { consumption and costs of grids. }\end{array}$ & $\checkmark$ & $\times$ & $x$ & [28] \\
\hline $\begin{array}{l}\text { Arbitrage optimization } \\
\text { algorithm }\end{array}$ & $\begin{array}{l}\text { A battery energy storage system (BESS) capable of } \\
\text { discharging for } 1.5-2 \mathrm{~h} \text { at maximum power and } \\
\text { provides quick response and energy arbitrage. }\end{array}$ & $\checkmark$ & $x$ & $x$ & [115] \\
\hline $\begin{array}{l}\text { CubeSat battery } \\
\text { algorithm }\end{array}$ & $\begin{array}{l}\text { Choosing electric power system (EPS) architectural } \\
\text { converters for solar panels and unregulated dc-bus } \\
\text { have the maximum efficiency. }\end{array}$ & $\checkmark$ & $x$ & $x$ & [101] \\
\hline MOA & $\begin{array}{l}\text { A double-layer metaheuristic optimizer provides a } \\
\text { novel stochastic technique for optimizing solar } \\
\text { hosting capacity in distribution networks. }\end{array}$ & $\checkmark$ & $x$ & $\times$ & [27] \\
\hline Stochastic algorithm & $\begin{array}{l}\text { Propose a simple statistical model to breaking a } \\
\text { battery energy storage system up into minor } \\
\text { segments that lead to significant increases. }\end{array}$ & $\checkmark$ & $x$ & $x$ & [107] \\
\hline JAYA algorithm & $\begin{array}{l}\text { Compact and optimized SOC estimating model for } \\
\text { statistical error values such as SOC error used to } \\
\text { validate the model's performance. }\end{array}$ & $\checkmark$ & $x$ & $x$ & [104] \\
\hline NA & $\begin{array}{l}\text { Reduce the amount of data sent by extracting } \\
\text { features voltage descriptive. }\end{array}$ & $\checkmark$ & $\times$ & $x$ & [116] \\
\hline NA & $\begin{array}{l}\text { Clean electric power using information and } \\
\text { communication technology (ICT), the user can } \\
\text { monitor the load, battery, and panel current. }\end{array}$ & $\checkmark$ & $\checkmark$ & $x$ & [117] \\
\hline GA & $\begin{array}{l}\text { The household load control system that included } \\
\text { (RESs) led to lowered cost of electricity from ( } 228 \text { to } \\
\text { 51) USD and the peak-to-average ratio (PAR) from } \\
2.68 \text { to } 1.12 \text {. }\end{array}$ & $\times$ & $\checkmark$ & $x$ & [108] \\
\hline $\begin{array}{l}\text { LMA, Gaussian } \\
\text { algorithm and } \\
\text { Trust-Region } \\
\text { Reflective Algorithm } \\
\text { (TRRA) }\end{array}$ & $\begin{array}{l}\text { Established microgrid system for testing and } \\
\text { simulation, focusing on dimensioning and control } \\
\text { techniques, the residue discovered less than } 5 \% \text {. }\end{array}$ & $\checkmark$ & $\checkmark$ & $x$ & [110] \\
\hline
\end{tabular}


Table 2. Cont.

\begin{tabular}{|c|c|c|c|c|c|}
\hline \multirow[b]{2}{*}{ Tools/Algorithm } & \multirow[b]{2}{*}{ Achievement } & \multicolumn{3}{|c|}{ Implementation } & \multirow[b]{2}{*}{ Ref. } \\
\hline & & $\begin{array}{c}\text { BM } \\
\text { Dc-Device }\end{array}$ & RE & $\mathrm{CC}$ & \\
\hline (SHEMS) & $\begin{array}{l}\text { The smart monitoring and control system preserves } \\
\text { and manipulates data from the PV, wind energy } \\
\text { conversion system (WECS), and batteries. }\end{array}$ & $\checkmark$ & $\checkmark$ & $x$ & [113] \\
\hline $\begin{array}{l}\text { Branch and bound } \\
\text { algorithm }\end{array}$ & $\begin{array}{l}\text { Propose an energy-efficient approach that can } \\
\text { operate in an online fashion ANN-based approach } \\
\text { outperforms all benchmarks. }\end{array}$ & $\times$ & $\times$ & $\checkmark$ & [111] \\
\hline $\begin{array}{l}\text { BMS-Master and } \\
\text { BMS-Slave }\end{array}$ & $\begin{array}{c}\text { Propose a cloud control strategy to enhance the } \\
\text { analytical electrical energy and information storage } \\
\text { in the cloud using lithium-ion and } \\
\text { lead-acid batteries. }\end{array}$ & $\checkmark$ & $\times$ & $\checkmark$ & [18] \\
\hline NA & $\begin{array}{l}\text { Propose a closed-loop program for an effective } \\
\text { management strategy for lithium-ion batteries by } \\
\text { concurrently changing factors. }\end{array}$ & $\checkmark$ & $\times$ & $\checkmark$ & [118] \\
\hline ETMCTSA & $\begin{array}{l}\text { Propose the energy-efficient hybrid (EEH) scheme } \\
\text { for increasing electrical energy consumption } \\
\text { efficiency using a single strategy to minimize energy } \\
\text { usage in terms of power use effectiveness (PUE) and } \\
\text { data center energy productivity (DCEP). }\end{array}$ & $\times$ & $\times$ & $\checkmark$ & [114] \\
\hline NA & $\begin{array}{c}\text { Design embedded network platform using smart } \\
\text { sensor gadgets with telecommunication functions } \\
\text { and molecular channel systems to maintain } \\
\text { battery health. }\end{array}$ & $\times$ & $\times$ & $\checkmark$ & [119] \\
\hline $\begin{array}{l}\text { Optimization } \\
\text { algorithm of } \\
\text { the HEMS }\end{array}$ & $\begin{array}{l}\text { The combine between a smart thermostat and } \\
\text { (HEMSs) a } 53.2 \text { percent decrease in daily costs is } \\
\text { obtained (TOU) }\end{array}$ & $x$ & $\times$ & $\checkmark$ & [112] \\
\hline
\end{tabular}

\subsection{Distributed Energy Resource}

DER are energy generating and storage systems that supply power where required. DER systems, which produce less than 10 megawatts (MWs) of power, may generally be scaled to fit your specific needs and can be installed on-site. Therefore, one single source is limited and can probably be costly, whereas to achieve efficient energy storage, a combination of all technologies is required. Power conversion systems for storage purposes must also be considered [120]. This is required to increase their control and dependability, as well as to ensure that storage systems are properly integrated into power networks [121]. A next-generation SG without energy storage is similar to a computer without a hard driveseverely limited [122]. A suitable EMS is required to obtain the optimum performance for clusters of distributed energy resources (DERs). The multi-agent systems (MASs) paradigm, as utilized and described, may be used to organize distributed control methods [123]. Some of the benefits of employing MASs for successful, intelligent grid operation in the energy market are discussed in [124,125]. The MAS application reduces the overall cost of power system production, integrated microgrids, comprised dispersed resources, and lumped loads [126]. To maximize the hybrid RE production system's economic performance and energy quality, a hybrid immune-system-based PSO was presented and applied to reduce fuel cost in the generating process [126].

Conversely, the distribution system operator (DSO) can dispatch at least a portion of the DERs; implementation of a coordinated integration of the various DERs recommends a centralized method. The best operating strategy of the DER system is generally analyzed by using a multi-objective linear programming methodology in centralized control methods [127]. The combination of the energy costs with the reduction of environmental effects suggest reducing operational costs, including energy losses, curtailed energy, reactive support, and shed energy [128,129]. Additionally implemented is a two-stage short-term scheduling process. The first task is to create a day-ahead scheduler to optimize 
DER production for the next day. In the second step, an intra-day scheduler that modifies scheduling every $15 \mathrm{~min}$ is also proposed, which considers the distribution network's operation needs and restrictions, as shown in Figure 5 [130].

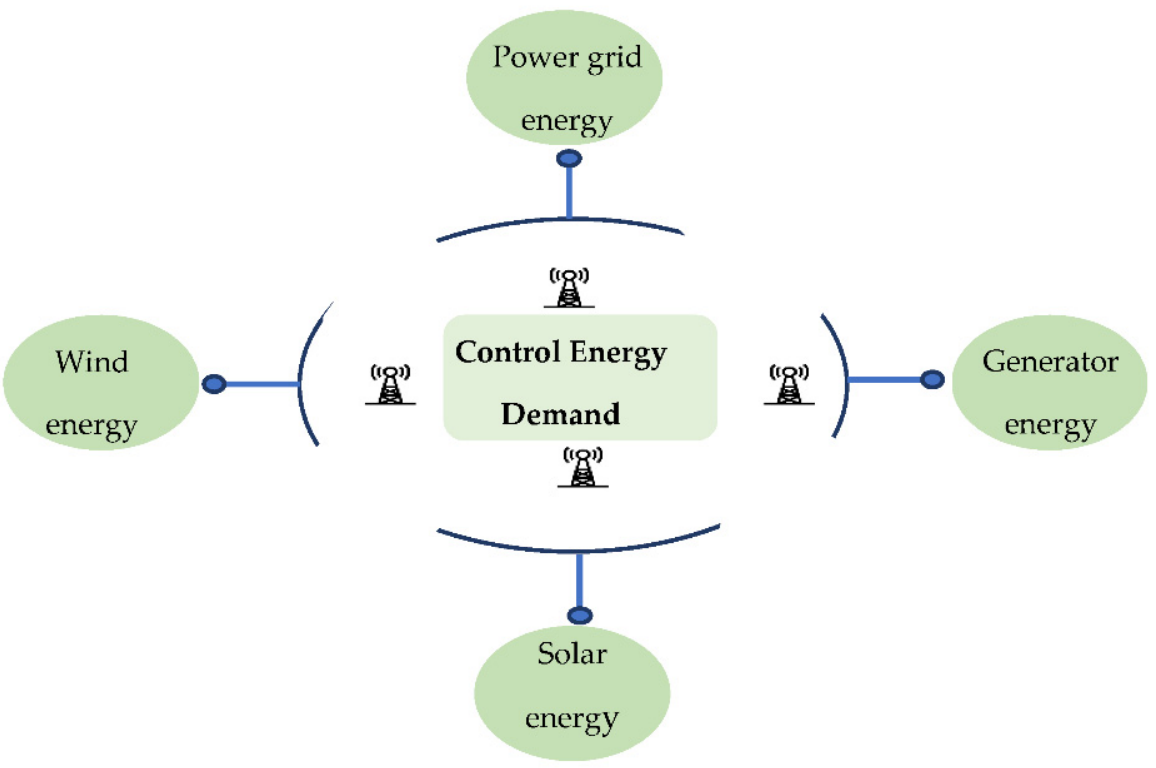

Figure 5. Schematic illustrating concepts of distributed energy resources.

\subsection{Microgrid Trading}

Microgrids are small-scale power networks that provide a more flexible and reliable energy distribution in limited geographic regions [131]. For fulfilling local demands, they generally use DERs such as distributed generating units and energy storage facilities. As a result, they can minimize dependency on the traditional centralized power grid (also known as a microgrid or primary grid in power system literature) that generally relies on massive central station generation [132]. Besides, the environmental benefits of using locally accessible RESs such as solar panels, fuel cells, or WTs also have economic benefits because if DERs and loads are physically close together, microgrids can minimize transmission and distribution losses [133-135]. A microgrid system was used to maintain the energy arbitrage, balance, reserve frequency regulation and transmission-level for voltage control, investment deferral, grid capacity support at the distribution level, time-of-use (TOU) cost management, etc. [136-138]. Furthermore, it considered as a detection device from the connected grid and operate autonomously in island mode if technical or economic situations demand, which is considered as local energy in the surrounding area [139]. Power delivery from a distance is inefficient because part of the electricity-as much as $8 \%$ to $15 \%$ - evaporates in route. A microgrid solves this inefficiency by generating power close to the people it serves; the generators are either nearby or within [140,141]. A microgrid system warrants research attention for several reasons: first, it is local, making electricity close to the people you serve; generators are near or within the building or on the roof in solar panels. The tiny network addresses inefficiencies in significant networks, which lose energy during transmission from producing units to transmission and distribution lines across vast distances. Second, it is independent and can be disconnected from the primary grid and run on its own. When the electrical system goes down due to a storm or other disaster, they must deliver power to their consumers. Third, the generators, batteries, and surrounding building energy systems are all controlled by microgrid intelligence. In addition, the controller coordinates a variety of resources in order to meet the energy goals of the microgrid's consumers, which can be searching for the cheapest energy, the cleanest energy, the most reliable electricity, or something else entirely. The controller accomplishes these objectives by raising or decreasing any of the microgrid's resources or combinations of those resources for optimum impact, as shown in Figure 6 [142]. 


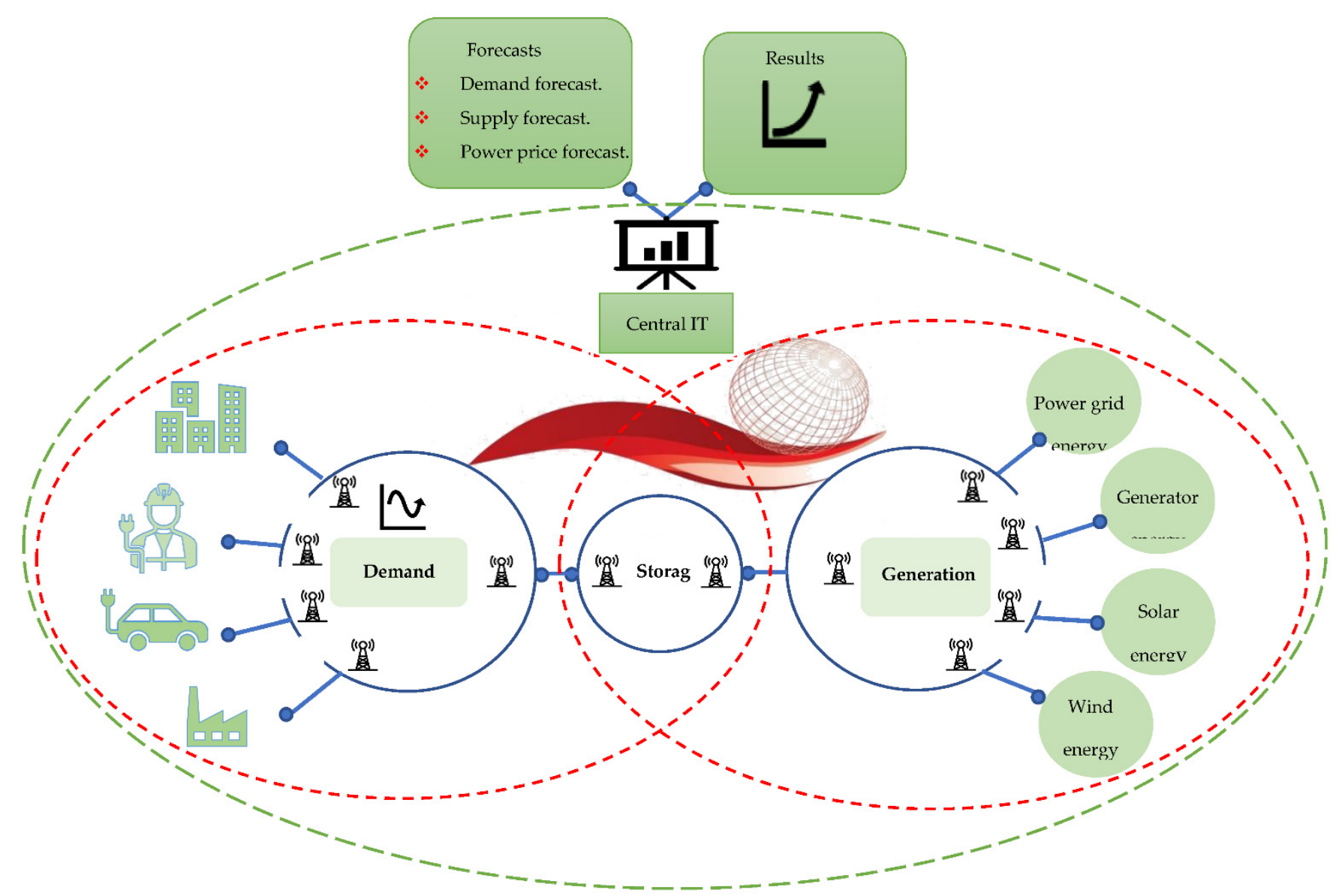

Figure 6. Schematic illustrating concepts of distributed energy resources.

\subsection{Virtual Power Plants (VPPs)}

Electrical energy has a significant impact on people's lives all around the world. As the demand for electricity grew, the power infrastructure and the global environment were placed under additional strain $[143,144]$. Buildings are a substantial producer of greenhouse gases (GHGs) $[145,146]$. An effective EMS is required to address the fast increase in demand [147]. Furthermore, several nations have committed to submitting an annual GHG emission reduction plan under the Paris agreement, making the use of (RESs) essential $[148,149]$. Due to the network's new topology RESs, traditional EMSs are no longer effective. In order to aggregate and accommodate RESs while considering geographic distribution and uncertainties, an optimal scheduling algorithm must be developed [150,151]. The VPP concept is one of the most promising and practical energy management solutions, allowing for unique features by integrating embedded technology and communication networks into the energy system. Despite the fact that Awerbuch and Preston proposed VPP in 1997, there is still no clear description for the VPP [152]. From a variety of perspectives, VPPs have been proposed in the literature. At the same time, the usual inclination is to aggregate DERs for energy management purposes [146]. Many research has concentrated on business and marketing factors [153]. Other publications, however, have emphasized technological viewpoints such as Internet of energy (IoE) [154], EMS [155], combination of RESs [156], an independent microgrid [110], or a data and connection system [117]. A trading platform used by DERs to make wholesale market contracts is known as VPP. VPP is a DER aggregator that considers the impact of the network on their output [157]. VPP is a control system for DERs, flexible loads, and storage that is defined as an information and communication system. According to the investigation, a VPP is a collection of DERs, controllable loads, and storage units combined to operate as a single power plant, with an 
EMS at its core [158]. VPP is defined as an aggregation of several DERs distributed at the distribution network's medium voltage (MV) level [159].

In general, several solutions have been presented in recent years to overcome the aforementioned difficulties. The VPP concept is one of the most promising energy management concepts, allowing for unique features through the integration of embedded technologies and communication networks into the energy system. VPP uses a bidirectional energy flow to provide real-time monitoring and energy efficiency. As a result, they were able to exchange their excess electrical energy on the market without the involvement of a third party [160]. Prosumers, conversely, who install any small-scale RES, or storage (batteries) can trade because the scheduling algorithm maximizes their surplus energy. Customers without RES or storage can also contribute by moving loads, trimming peaks, and filling valleys, among other things. Lastly, through enhancing operating planning, VPP may conform with power administration rules [161,162], as well as the five main areas that best illustrate the scope of the intelligent grids system, such as DR, PS, DER, MT and VPPs, as shown in Table 3.

Table 3. Main scope of the smart grids system.

\begin{tabular}{cc}
\hline Main Scope & Description \\
Demand Response & $\begin{array}{c}\text { A novel technique makes virtual generation better. Users may program their gadgets for } \\
\text { interaction with the power grid to improve load profile, and user power usage costs should } \\
\text { be reduced without compromising their pleasure. }\end{array}$ \\
\hline Power supply & $\begin{array}{c}\text { An electrical device transforms electric current from a source to the proper voltage, current, } \\
\text { and frequency to power an electrical load. }\end{array}$ \\
\hline Distributed Energy Resource & $\begin{array}{c}\text { Systems for producing and storing energy for efficient storage and production that distributes } \\
\text { electricity where it is needed. }\end{array}$ \\
\hline Microgrid Trading & $\begin{array}{c}\text { Small-scale power networks provide more flexible and reliable energy distribution in limited } \\
\text { geographic regions for fulfilling local demands. As a result, it can minimize dependency on } \\
\text { the centralized power grid by detaching and operate autonomously to reduce transmission, } \\
\text { distribution losses, energy arbitrage, balance. }\end{array}$ \\
Virtual Power Plants & $\begin{array}{c}\text { It is the most important future solution that can be applied in energy management, and } \\
\text { integrating systems and networks into the energy system is a system of telecommunication } \\
\text { and information that controls DERs, loads that are adaptable, and storage. }\end{array}$ \\
\hline
\end{tabular}

\section{Cloud Computing}

Cloud computing is an useful computing paradigm that provides on-demand access to facilities and shared resources over the Internet [163]. Infrastructure as a service (IaaS), platform as a service (PaaS), and service as a service (SaaS) are three notable services it offers, while storage, virtualization, computing and networking are supported [164,165]. Implementing cloud computing applications is a top priority, especially in today's environment, for things such as providing appropriate financing for social services and purchasing programs. Grids are geographically distributed platforms for computation. They provide high computational power and merge extremely heterogeneous physical resources into a single virtual resource $[166,167]$. Grid computing is a set of resources; the primary resource is the central processing unit (CPU), which is mainly used to perform massive and complicated calculations. Cloud computing technology is used by the majority of existing information technology (IT)-based enterprises. Cloud computing is a rapidly evolving technology, and companies are constantly adding new services to their cloud environments to stay competitive and fulfill customers' expanding demands [168]. Furthermore, many different organizations are moving their IT-based systems to cloud-based models [169]. Customers can use cloud computing resources in the form of virtual machines (VMs) that are deployed and run-in data centers. The data centers are composed of several physical servers, each with its own set of resources [114]. The cloud computing ecosystem for energy management is described in Figure 7. 


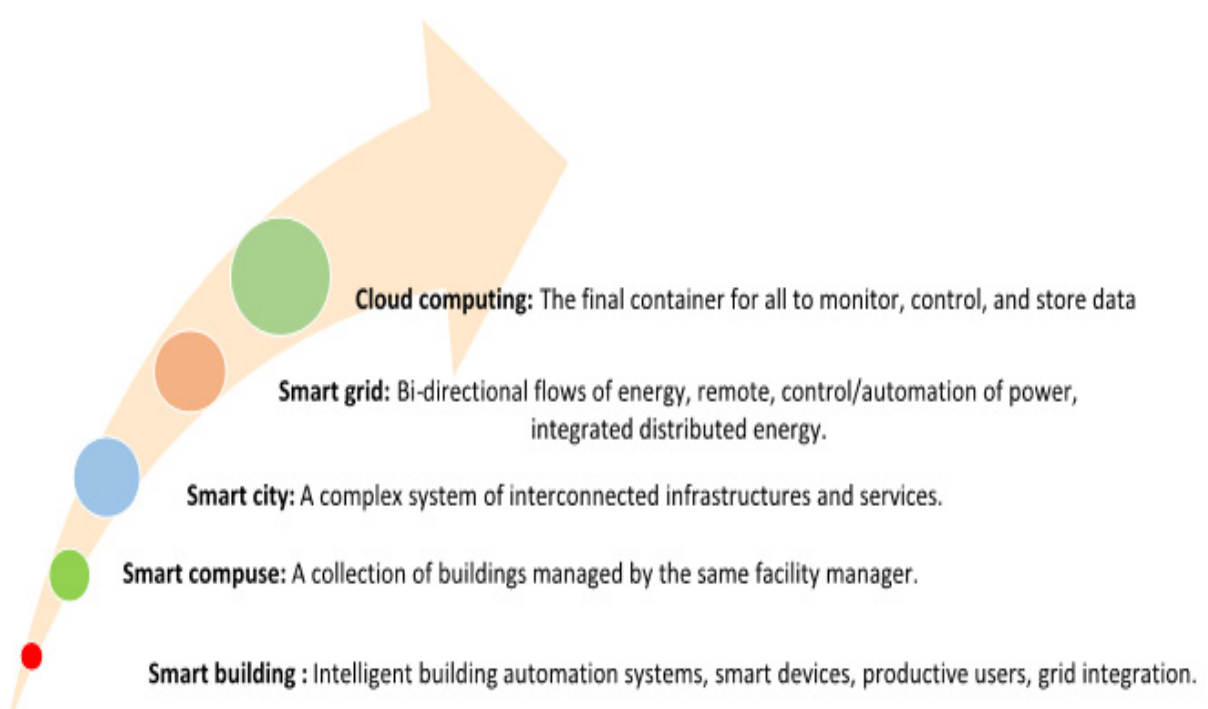

Figure 7. The cloud computing ecosystem for energy management.

\subsection{Cloud Computing and Storage of Data}

The IaaS model of cloud computing provides consumers with storage services. People have begun to save their data on clouds due to the large storage capacity $[170,171]$. Through virtualization, the issues around the storage of user data IoT applications can be solved by providing storage, processing, and networking resources [172]. In mission development, two-measure CPU usage and storage capacity are the best typical capabilities of the cloud to reduce local storage overheads [173]. These parameters' significance may minimize computation cost, communication, $\mathrm{CPU}$ usage reduction, and battery and data redundancy elimination in terms of storage and computing by performing task scheduling. Research on storage techniques has gained momentum due to the significant advantages of quick storage services in the cloud. Still, these techniques have specific challenges because there is a higher demand for quick access and secure storage. Cisco predicts, that by 2021, cloud computing systems will account for around 94 percent of all computing. Furthermore, by 2025 , the size of data created and altered is expected to reach 175 zettabytes, according to International Data Corporation (IDC) [174]. The aforementioned necessitates cloud suppliers to establishing and simplifying additional services $[114,169]$.

\subsection{Cloud Computing and Software Services}

Cloud computing using virtualization technology offers end-users computational resources, on-demand resources, flexibility, dependability, dynamism, scalability, and better availability wherever and at any time, which are examples of different services [175]. Elasticity is one of the keys characteristics of cloud computing, which refers to the system's capacity to respond to changes in workload [176]. Cloud services are now employed in most applications via the internet, which has become the contemporary economy's backbone. As a result, resource scheduling has become a hot topic in the cloud because ineffective scheduling techniques can lead to a variety of issues, including long computation times, reduced profit, poorer throughput, higher cost, and inappropriate resource usage, which are all examples of an uneven workload at resources (over-utilization or under-utilization) [177]. Resource usage in cloud computing is directly related to power consumption when resources are not used properly (over-utilization or under-utilization) due to high processing demand from end users and no service delays from the cloud. Integrating energy-sensitive servers has become a popular topic in the cloud world [178]. Therefore, future research is required to address the challenges and meet end-user demand within a reasonable timeframe. Reducing power consumption by switching underused hosts to sleep or hibernation without violating service level agreements (SLAs), which are digital contracts between end users and cloud services, ensures quality of service while 
resources are ready. Therefore, several energy-conscious server integration methods have been proposed in the last decade [179]. Either of the two scenarios is intended to achieve server consolidation. Most of the suggested scheduling methods must strive toward greater resource utilization and energy efficiency. However, most available algorithms are still in their infancy due to constraints [180]. Most algorithms focus on a single parameter (energy) and ignore other factors such as cost, reaction time, elasticity during run time, etc. [181].

\subsection{Cloud Computing and Energy Savings}

Local or green power sources are considered an excellent method to conserve energy at a data center by locating it near where the electricity is generated to reduce transmission losses [182]. Shutdown, hibernation, and sending in various low-power stages are examples of cloud computing approaches. At the same time, cloud computer energy consumption should be managed to optimize energy consumption for a specific computing task. When it comes to reducing energy usage per unit of work, cloud computing is a more energy-efficient option [183]. According to studies, employing the cloud might result in a 38 percent reduction in global data center energy expenditures by 2020, but a 31 percent reduction in data center power usage (from 201.8 terawatt-hours (TWh) in 2010 to 139.8 (TWh) in 2020). According to another report [183], cloud computing might help businesses save billions of dollars on their energy expenses. This equates to a reduction in carbon emissions of millions of metric tons each year [184].

\subsection{Cloud Computers as VPPS}

A VPP is a network of multiple tiny power stations (a cluster of dispersed generation facilities, such as microchips, WTs, small hydro, backup gensets, etc.) that operate as if they are one power unit [185]. There is a necessity to check the cloud computing entity linked to the power network in multiple locations, frequently given by several suppliers, connected to different distributors, and operating in multiple countries at the same time [186]. Energy consumption can be managed with specialist software designed for cloud computers and based on the VPP concept; generators are seen as resources and flexible users in the same way that cloud computers are [187]. Furthermore, the cloud computer is a potentially adaptable consumer. The cloud computer software already aggregates and controls its consumption; therefore, it performs the function of a VPP [187]. Existing cloud systems as consumers and energy systems as producers are separate systems that typically operate in parallel with little cooperation during one-way PS. To attain higher overall performance, such parallel networks require more complicated interaction [188]. The load provided by cloud computer centers provides a reliable picture of consumption demand. This energy storage device is an effective way for owners to reduce electric power prices while also reducing demand on the power grid [189]. The SG should be sensitive to the electricity system's present load. The computational cost of methods to minimize power consumption is determined by the required delay and the amount of load to be reduced. These application execution and scheduling models will need to account for cloud resource availability [190,191]. This strategy could include launching more VMs as demand for power rises, or expanding cumulative bandwidth capacity to handle a higher sampling rate of streaming data [185].

\section{Big Data}

With the increased use of numerous digital devices that generate heterogeneous, structured, or unstructured data in recent years, the volume of data has exploded, culminating in what is now known as huge data [192]. Traditional database systems have proven inefficient when it comes to storing, processing, and analyzing large amounts of data [193]. As a result, handling big data is a critical component of business and management rivalry. Nonetheless, it has posed a new challenge for both science and industry in terms of information and communication technologies, driving the development of data-centric architectures and operational models [194,195]. 
Since normal tools and methods are not built to manage such huge data quantities, the emergence of big data has highlighted a serious management dilemma [196]. At the same time, conventional infrastructures are unable to meet the distributed computational needs of managing vast amounts and types of data. This is owing to the increasing number and complexity of data sets, as well as their volatility, which makes processing and analysis difficult to perform using standard data management approaches and technology [197]. Current infrastructure struggles to keep up with massive amounts of data, yet it is a difficult task [198]. The current methods and technology for handling big data management issues place a premium on volume, variety, and pace [199].

Moreover, big data comprise complex data that are massively produced and managed in geographically dispersed repositories [200]. To handle enormous data difficulties, innovative management strategies and technologies are motivated by this complexity [201]. Although there have been several studies on giant data management, none have been thoroughly investigated. Giant data mechanisms are summarized in Figure 8.

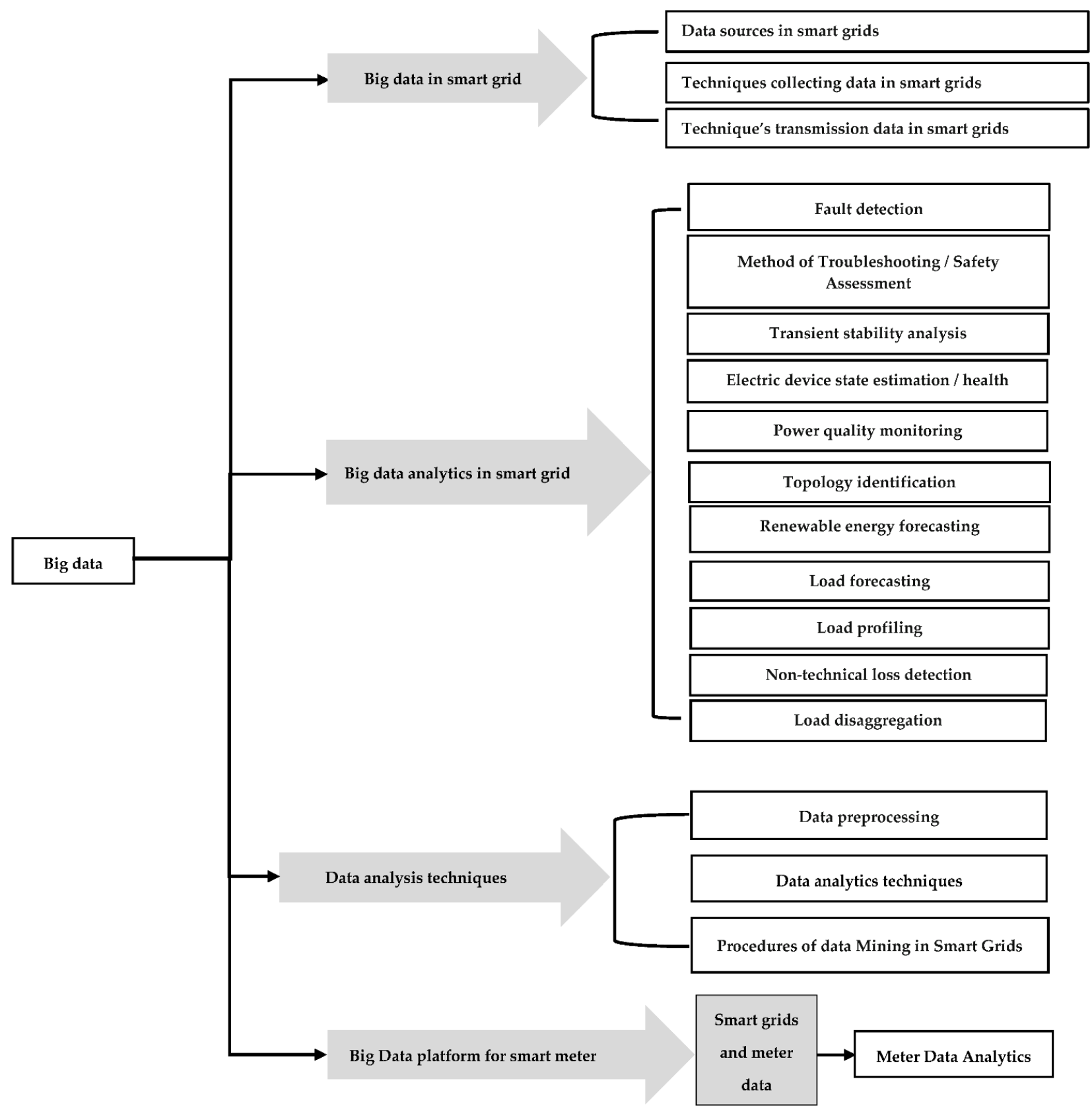

Figure 8. Big data mechanisms. 


\subsection{Big Data in Smart Grid}

An intelligent grid architecture model includes a framework from three dimensions that combines layers, zones, and in the realms of generation, transmission, distribution, DER, and customer premises, there are several domains to evaluate a SG [202]. An energy network with an embedded information layer generates a large amount of data in the grid, such as measurement techniques and monitoring instructions, which must be collected, transmitted, stored, and analyzed quickly and comprehensively [203]. The data analysis platform also presented several opportunities and difficulties [202,204]. The massive data characteristics in SG in many studies are consistent with the widespread $5 \mathrm{~V}$ vast data paradigm as shown in the Table $4[205,206]$.

Table 4. Main features of big data in smart grids as revealed.

\begin{tabular}{cc}
\hline Features of Big Data & Description \\
\hline Volume & $\begin{array}{c}\text { Smart meters and advanced sensor technologies are becoming more widely used in the SG generates } \\
\text { a tremendous quantity of data. As a result, standard database technology can't store or interpret data } \\
\text { sets that are too big. }\end{array}$ \\
\hline Velocity & $\begin{array}{r}\text { The rate at which new data are created and moved while the demand for real-time data sharing is } \\
\text { growing and posing a new issue. }\end{array}$ \\
\hline Variety & $\begin{array}{r}\text { Words, digital images, detector data, and video are examples of unstructured data that may be } \\
\text { integrated with typical structured data utilizing big data technology. }\end{array}$ \\
\hline Veracity & $\begin{array}{c}\text { The messiness and trustworthiness of the data. The effective management of the electricity system is } \\
\text { based on data analysis and state estimate. Therefore, the data transfer faults or devices and a large } \\
\text { amount of big data lead to problems in the data analysis results, as well as measurement mistakes. }\end{array}$ \\
\hline Virtual & $\begin{array}{r}\text { The capability to draw out important data from massive amounts of data while maintaining a clear } \\
\text { sense of its worth. Big data makes obtaining valuable information harder. }\end{array}$ \\
\hline
\end{tabular}

\subsubsection{Data Sources in Smart Grids}

SGs, similar to intelligent energy and information system, have a variety of data sources. Data is collected from sub-stations, distribution switch stations, and power meters [207]. In addition, nonelectrical data such as trade, economic data, etc. are included in the information source. For power plant scheduling, subsystem functioning, essential power equipment maintenance, marketing business behavior, data collecting and analysis are considered critical [208]. Measurement, business, and outer data are the three types of data sources described above [209]. Most power system operating characteristics are assessed using installed sensors and smart meters that offer data on the system's present and historical condition [210]. Social activity such as carnivals and weather conditions are examples of data from outside sources that cannot be monitored by smart meters, yet still affect the work and design of the electricity system. The data for business mainly consist of trading techniques and customer demand [211].

\subsubsection{Techniques Collecting Data in Smart Grids}

The intelligent grid collects and sends data from intelligent meters, providing energy information to all companies and customers [212]. The amount of intelligent meter readings for residential customers is anticipated to increase from 24 million per year to 220 million per day for a prominent utility provider [210]. In high voltage (HV)/MV transformers for voltage control, the present magnitude data is required for the automated on-load tap changer [213]. A standard intelligent meter measures voltage at the node, current at the feeder, load conditions, reactive power flow, and energies over time, complete concord alteration, and load up demand and among other things [214]. 


\subsubsection{Techniques Transmission Data in Smart Grids}

The smart grid's foundation communication is divided into home space networks, district space networks, and wide-space networks $[215,216]$. The most common forms of communication methods for intelligent meters are wired and wireless infrastructures [217]. The technique of wireless connectivity allows acquiring measurement data from intelligent meters at low prices and simple interfaces while the data center may encounter a magnetic challenge [218].

\subsection{Data Analysis Techniques}

Data analysis is the most crucial stage of the hug system for data processing that provides the foundation for uncovering useful information and assisting in decision making [219]. Data analytics, often known as data mining, is a computer process that uses techniques such as database, statistician, design detection, and expert system to uncover the possible relationships between variables [220]. However, the resulting data sets may have varied performance in terms of noise, repetition, and uniformity due to the many sources [221].

\subsubsection{Data Preprocessing}

Data integration strategies seek to effectively combine data from several sources into a single picture $[222,223]$. Densification of data preprocessing techniques to eliminate highly linked variables and minimize dataset size due to some algorithms for analysis of the data can be sensitive to imbalanced data [220]. A logarithm helps correct the distribution form of data with severe weakness if the original dataset only contains the highest and minimum temperature values [219]. Additional features such as temperature differential might be computed through the preprocessing stage if the source dataset only has the most significant and lowest temperature values. These characteristics are frequently beneficial in improving the accuracy of data analytic findings [221].

\subsubsection{Data Analytics Techniques}

The model for data analytics may be developed based on the provided data to identify the relationship between aspects and the associated types or values using supervised learning techniques. When analyzing an unnamed data approach, it is typically designed to identify the different classes across all objects [224].

\subsubsection{Procedures of Data Mining in Smart Grids}

The fundamental purpose of data analytics in the SG is to extract useful information from historical data and compare it with real-time data to guide operation and maintenance [225]. Data management strategies are used to organize and store the massive amounts of data gathered through intelligent meters and sensors. Following that, a mathematical model may be created using data mining techniques and clean data [226]. The status may be assessed in the generated model using real-time data, which gives potential strategies for guiding actual activities and resolving any issues [227,228].

\subsection{Big Data Analytics in Smart Grid}

\subsubsection{Fault Detection}

The SG is considered the driving force in the distribution arrangement system to reduce carbon release and create environmental sustainability [229]. Using distributed generation units in current power distribution networks enables the optimal use of widely available RESs such as wind and solar energy [224]. Furthermore, the microgrid's proximity to the generator power delivery dependability is improved, and power transmission loss is reduced. The ability to operate in island mode also protects the load from harm caused by power system issues such as voltage fluctuation, frequency deviation, etc. [229]. However, RE has an intermittent nature, which adds to the grid's unpredictability. When a large quantity of temperature or energy damages microgrids, the typical sized generators 
are unable to identify and fix the problem in a timely manner due to their low load capacity, posing a serious threat [230]. Most standard approaches, which focus on detecting overcurrent and negative sequence currents in large-scale centralized power systems, appeared ineffective in microgrids [231].

\subsubsection{Method of Troubleshooting/Safety Assessment}

Distribution automation (DA) focuses on the distribution level's functioning and system reliability. A successful DA can locate and isolate distribution system issues, resulting in faster restoration times and more customer satisfaction [232]. A growing amount of operational data is being collected via supervisory control and data acquisition (SCADA) or sophisticated metering infrastructure for status monitoring and problem diagnosis advanced metering infrastructure (AMI) [231]. A significant amount of data may be captured through AMI and communication foundations due to the advancement of green information and communications technology (ICT) technologies in energy systems [233]. A data-driven model of failure phenomena based on a hybridization of evolutionary learning and clustering methodologies is the input of a one-class, power system operational data, weather data, and relay protection device log data [234]. For accurate online identification of dangerous occurrences in the power system, the extreme learning machine (ELM) algorithm is used in an intelligent early warning system. The learning speed of ELM training is significantly quicker than traditional algorithms since the weights are arbitrarily generated and then calculated by matrix computing lacking iterative parameter modification [235]. The data-driven framework's ideal balance between earning precision and warning acuity is also explored. Using a ranking system, it extracted electrical features from high-impedance fault current and voltage data and generated an effective feature set (EFS) [236]. Thus, a statistical classifier for defect detection may be made using a limited number of signal channels. It also shows how to minimize many phasor measurement units (PMU) of data while keeping the important information for power system failure detection [237].

\subsubsection{Transient Stability Analysis (TSA)}

Transient stability is a key issue that is closely linked to the power system's safe operation. However, rising electricity consumption, rising RE penetration, and a deregulated market all drive the power grid to operate at or near its safe operational limitations [238]. According to the SG concept, massive data gathering by AMI contributes to the situation evaluation of energy systems, while assisting with energy administration, functioning of a system, and decision making [239]. As a result, effective recapitulation algorithms are necessary for identifying meaningful patterns and uncovering important information from the duplicate evaluation in the power system [240,241].

In addition to green energy sources deployed via the SG, wind farms are being implemented to utilize abundant and emission-free natural resources and the extensive installation of wind energy in the grid by addressing possible deterioration and instability caused by the extensive installation of wind power into the electricity network [242]. Energy fluctuation is the swing of the energy stream on the transport line caused by concurrent machine rotor angles advancing or regressing to each other, which produces high interruptions. High-pressure dropping, engine activation, and clearing short-circuit problems are all possible causes [243]. However, using a decision tree (DT)-based technique for defect detection and categorization within the half-cycle time during power swing [244], the DT-algorithm was used with 21 possible characteristics derived from phasor measurement unit (PMU) data following the Kalman filter procedure for smart relaying in the power system [245]. The DT and graded aggregate created a probability frame for the dynamic performance of energy systems following a disturbance [246]. The unbalanced groupings that may break synchronism could be identified effectively. Although the PMU and wide area monitoring system (WAMS) give clarity information for designers to uncover patterns of stable and unstable operation, the low likelihood of events occurring in the power grid has resulted in a significant issue of class disparity [247]. It is difficult to discern the characteristics of 
uncommon instability from significant synchro phasor observations using traditional data analytics [248]. A systematic one-sidedness learning appliance for short online voltage evaluation is being developed to fully utilize enormous electricity grid data [237]. To show the power system parameters and external data such as meteorological information, the random matrix theory was combined with a high-order data-driven model $[249,250]$. The eigenvalue-based analysis method has been shown to be effective for analyzing online transient states [251]. Based on parallel computing and K-nearest neighbors learning methods, a live monitor of instantaneous electromechanical dynamics in transmission systems is given [252]. The suggested framework is used to handle the massive amount of PMU data from the power grid and extract information showing time-varying power generation and consumption $[253,254]$. For an online assessment evaluation of the (TSA) problem, the core vector machine (CVM) model is trained offline using 24 characteristics taken from the raw data [234]. A statistical nonparametric regression methodology based on the critical clearing time was used to examine the temporary stability boundary of large-scale power systems in order to assess if a steady-state condition can recover after a particular fault [255].

\subsubsection{Electric Device State Estimation/Health Monitoring}

Power transformers are critical components for electrical energy conversion, and their failure can result in catastrophic blackouts in the power system. As a result, research into the life-cycle administration of power transformers founded on precise estimates has sparked considerable interest in a more stable and dependable power system [256]. Three traditional methods for association rule mining, including apriori, aprioriTid, and aprioriHybrid, are presented to obtain data about system processes and climatic circumstances into state estimate examinations [257]. For possible failure prediction, rule mining approaches are coupled with a probabilistic graphical model. Building automation systems (BAS) are developed and implemented in most commercial buildings to regulate the heating, ventilation, and air conditioning (HVAC) system to repair optimum heat and humidity for the inhabitants [258]. FL was used to offer a unique health monitoring system for detecting abnormal operating conditions [259]. In a power system, the number of aged assets grows, and various failure models based on variables such as aging time or circumstances have been developed. As a result, lifetime data such as service age, maintenance, and health index were used to create a failure rate model for general electric power equipment [260]. The stratified proportional hazards model (PHM) for processing and classifying lifetime data into multi-type frequent occurrences was created to make the most effective use of this data [261]. This PHM technique may be used to predict possible risk issues and health conditions [262].

\subsubsection{Power Quality Monitoring}

Electric PQ is the magnitude, frequency, and waveform of voltage and current in power systems, and it is closely linked to the power grid's safe functioning and consumer satisfaction [263]. In the electrical grid, nonlinear, power electronics-based loads, generators, harmonic distortions, and unstable situations are becoming more common [264]. In some residential areas, traditional electromechanical analog meters still work, and data analyticsbased PQ analysis cannot be used effectively [264].

\subsubsection{Topology Identification}

Using information layers in the SG to address the problems posed by RESs in supplying the network is a viable solution [265]. SGs are becoming more sensitive and perceptible by improving sensors and gadgets that measure, monitor, communicate, and regulate them [266]. Because of the unpredictability of RES and the uncertainty of the load, a comprehensive decision based on a large quantity of data collection and analysis is required [267]. The SCADA and WAMS systems provide intelligent grid voltage and power data at sampling rates that are close to real-time [268]. The network model is built using 
both graph theoretical and probabilistic optimal DC power flow technologies that are low in carbon, which is being pushed by the government using warmth pumps, photovoltaics, electric cars, and other intelligent appliances in little voltage (LV) sharing networks to create a greener society $[269,270]$. As a result, there is increasing interest in visualizing LV networks using restricted metering and data collecting equipment [271]. A cost-effective option is network load profiling, based on identifying typical load profiles of LV systems. A three-stage network load profiling technique described by clustering, classification, and scaling seeks to analyze the current LV networks' capacities to accommodate the technologies that are low in carbon [272].

\subsubsection{Renewable Energy Forecasting}

Wind and solar energies are expected to be the essential sources of energy for the power grid, due to the plentiful and environmentally beneficial generation of energy [273]. Conversely, randomness and intermittent features are constant roadblocks to the constant largescale use of RES. The precise and reliable RES predicting technique has been the hot point worldwide to cope with such massive difficulties and to enhance dispatch planning, maintenance scheduling, and regulation [274]. The meteorological data is utilized to categorize the days into distinct groups. Then, a neural network is qualified to obtain wind energy forecasting data $[275,276]$. PV diffusion is forecasted using a data-driven approach. The suggested regular neural network (RNN) model is designed for ultra-shortterm solar power forecast by deconstructing time-series information using distinct wavelet transform [277,278].

\subsubsection{Load Forecasting}

The actual short-term load projecting such as the RES estimation is the foundation for energy administration, system process, and market analysis [279]. Improving forecasting accuracy may result in several advantages and cost savings, as stated in [280]. The dynamic and highly efficient electricity of marketplace is constructed on accurate forecasts of energy consumption as customers frequently use smart networks to avoid neural network installation issues with a unique level of integration that overcomes load profile instability and uncertainty [281,282]. As part of the newest deep understanding approaches for residential load forecasting, a recurrent neural network-based framework with long short-term memory is used [283]. A hidden-mode Markov decision model is developed to predict user behavior in real time [284] and to analyze the latest phase of leveraging societal mass media via cell phone applications to increase consumer interaction and load forecasting [285]. In addition, the developing trends and obstacles examine the influence of social activities on prosumers' creation and consumption habits and the whole effect on final load and network usage [286].

\subsubsection{Load Profiling}

Load profiling refers to the process of describing the usual behavior of electric consumption [287]. In general, demand-load forecast management and capital planning in the time domain are expressed as an effective method of energy management $[288,289]$. The rationale for the best DR mechanism is to break down household energy consumption into three portions: stable, controlled and deferred loads [290]. DR is used to encourage consumers to modify their usage or feed-in patterns with a stimulant of charges or ecological data [291,292]. A good consideration of the unchangeable energy used by clients is the foundation for DR, that could relieve the distribution system's burden in terms of temperature and voltage constraints [293]. Knowing the charging load type of electric vehicles (EVs) is limited to be a critical phase for the constancy of power grids as they become more widespread [294]. To extract the charge-load model of an (EV) by measuring the actual power, Bayesian maximum probability is utilized to check the pliability of the collective EV charging demand [295]. Increasing the acceptance of smart meters placed according to the home standard, emphasizes the problem of enormous load profile data, 
which poses problems to measurement data transfer and storage, along with important data extraction out of the vast records [294-296].

\subsubsection{Load Disaggregation}

Non-intrusive load monitoring (NILM) is a type of load that separates general load profiles at the home standard from the power usage of specific machines [297]. NILM, out of just one smart meter, placed in the house is effortless to accept by clients than direct appliance monitoring framework [298]. The various types of residential electric machines possess varying possibilities for participation in the DR program, leading to a better understanding of their customers' behavior and a more energy-efficient approach [299,300]. NILM early approaches were mostly centered on detecting an edge in power transmission to indicate whether a recognized device is on or off $[301,302]$.

\subsubsection{Nontechnical Lack Detection}

Non-technical lack (NTL) most often results in electrical rubbery or accounting mistakes of power system companies [303,304]. Non-cooperative game models for nontechnical lack examination of micro-distribution systems applied to AMI [305]. A report by Northeast Group, Limited Liability Company (LLC), shows annual losses due to power theft that were more than USD 89.3 billion worldwide [303]. Furthermore, large-scale electricity theft has the potential to generate dangerous power system imbalances. As a result, many researchers are interested in developing a practical outline to identify the NTL in a composite energy system, which is an approach constructed on the DT and backed by suggest vector machine (SVM) [292]. DT is programmed with various parameters such as heavy appliances, the number of people in the house, and climate circumstances to calculate the predicted rate of power used for the client at any given moment. The computed consumption is then sent to an SVM classifier that has previously been trained on the gathered data set to assess if the customer's conduct is regular or fraudulent. Fraud recognition is triggered, as a difference is found between power provided by the energy system and gathered data out of the smart meters. Therefore, the fuzzy clustering technique is used to find abnormalities in consumption patterns [292].

\subsection{Big Data Platform for Intelligent Meter}

\subsubsection{Smart Grids and Meter Data}

SGs are classified into three parts, which are the information infrastructure (data stream in the smart grid's cyber portion), computer networks (exchange control signals and measurement data) [306], and power infrastructure (energy distribution in the physical component of smart grids), which includes intelligent meters and energy devices such as towers, generator and adapters [307]. IT components include modeling, analysis, profitable transactions, information exchange, and management [308]. Big data management and analytics are the key problems in the SG [202]. Smart metering is causing a huge growth in the volume of data available. For example, in the United Kingdom, approximately 100 million data points are gathered biannual for energy companies to register for the 27 million residential power users. Power suppliers will be essential to absorb, store, and fully analyze 4500-9000 times more data when smart metering is perfectly installed and operating at a 30-min sample rate. The capacity to cope with massive data problems in the future will be critical for several essential intelligent grid applications, including situation awareness, state estimate, event discovery, load forecasting, and claim response administration [309].

\subsubsection{The Analytics of Meter Data}

The techniques of mining data are used to analyze the meter data of a variety of applications. These may support energy managers in uncovering knowledge and obtaining insights from large data [310]. The majority of the research is proven via utilizing comparatively modest data collections, such as claim or carry out forecasts [311], customer 
segmentation, pattern categorization, recommendations of power tariff, power consumption of equipment in particular homes, and demand-side management [312]. One of the most recent huge data sets published was over one million data points-still far from the predicted future [313,314].

\section{Challenges}

This section highlights three energy issues that remain unresolved in cloud computing applications for smart grids: energy distribution, energy mix and battery charging. Therefore, there is a challenge of migrating SG to cloud computing for energy management, information management, and cloud applications [315]. First, open issues for energy management, similar to clouds, have a variety of heterogeneous applications. The microgrids lead to challenging transmission of data between the cloud and the microgrids with/without real-time data. Therefore, it is urgent to install a virtual power stream controller to optimize the energy that can operate in any realistic and efficient mode for the smart grid. However, to reduce a claim from micro-grids during summit hours, it a necessary to mix and share energy storage with a cloud [316]. Second, problems for managing information, despite cloud computing being effective at managing smart-meter data, still have several obstacles to overcome [317]. Solving data-sharing issues is an excellent idea for combining public and private clouds for cost-effective communication in smart grids. In addition, the integration of mobile multi-agents in cloud computing may achieve an effective intelligent network process, which is still a problem due to heterogeneous communication architecture. It must be able to accommodate diverse energy sources while also allowing for large-scale interactive collaboration via cloud services and a reduction in cloud app delays. As in billing, users need dependable and cost-effective services. A single protocol failure may bring the entire intelligent grid system down [318]. Third, long-term evolution (LTE) allows for better coverage and lower latency, which presents challenges to existing cloud computing platforms. Platforms that address some of the long-term evolution problems related to quality of service (QoS) improve with the radio access network, network of mobile core, and datum center to supported virtualized infrastructural resources. Coordination and synchronized function are encouraged facilities for monitoring, preprocessing, dissemination, storage, analysis, and alerting metrics supported between different clouds, which is a unified and suitable interface. The world's most pressing concern is energy. As a backup generator, fossil fuels are frequently employed, although their production of $\mathrm{CO}_{2}$ affects life and the environment [39]. A novel technique called DR makes virtual generation better. Users may program their gadgets using this approach. There are several issues with a traditional smart-grid design (without the cloud), which is the master-slave design that leads to a risk of DDoS [41,42]. Any error may cause the entire system to fail. There is a limit on how many clients can be served due to memory storage limitations, stability, and management. Furthermore, information and data management challenges include millions of intelligent meters necessitating effective handling of massive data. Cloud computing may provide a cost-effective alternative for data analytic and storage methods, as shown in Table 5 [319]. 
Table 5. Main features of big data in smart grids.

\begin{tabular}{|c|c|}
\hline Category & Challenges \\
\hline Smart grid & $\begin{array}{l}\text { - Heterogeneous } \\
\text { - } \quad \text { Nonergy storage systems are insufficient. } \\
\text { - } \quad \text { Big data management and analytics }\end{array}$ \\
\hline Cloud computing & $\begin{array}{l}\text { - } \quad \text { Data-sharing issues } \\
\text { - } \quad \text { Lack of integration of multiple mobile agents with the cloud } \\
\text { - } \quad \text { Insufficient platform Implementation for offering long-term evolution } \\
\text { - } \quad \text { Unsynchronized function } \\
\text { - } \quad \text { Risk of DDoS } \\
\text { - } \quad \text { Any error leads the system to fail } \\
\text { - Insufficient methods data analytic and storage methods }\end{array}$ \\
\hline Big data & $\begin{array}{ll}\text { - } & \text { Memory storage limitations } \\
\text { - } & \text { Stability } \\
\text { - } & \text { Management } \\
\text { - } & \text { Insufficient methods for handling massive amounts of data } \\
& \text { Information and data management challenges }\end{array}$ \\
\hline
\end{tabular}

\section{The Framework of the Charge Controller System}

Overall, after the long review illustrated in this paper, the proposed framework contains an EMS stored on the cloud computing service. This system serves three different goals. The first is to monitor and combine different energy sources in order to obtain the best optimized system. The second goal is to control the switches in the energy hub, and the third goal is to manage the charging and discharging process. The system will yield many benefits:

a. Reduce the carbon footprint by including RESs such as solar plants (photovoltaic), WTs, and other RESs;

b. Enhance the demand power by monitoring and controlling the power balance at the same time;

c. Introduce an intelligent system and cloud computing to the power management field, and make the system manageable.

It is difficult to carry out an actual optimization charge controller on an intelligent power system via cloud computing, as it is based on numerous nonlinear parameters and contains many genuine bonds and limitations. Furthermore, because many actual characteristics are stochastic, handling a power system as a plant (dynamic systems) is problematic. Therefore, there are two suggestions: the first is to plan the optimization algorithm for the charge controller based on the real parameters; the next is to implement this proposed algorithm as a practical system that offers optimal interventional treatment solutions for all protection requirements. Therefore, this study focuses on presenting a final chart of the model that will consider three aspects: power demand management, RE, and cloud computing, which will be the main contribution of the future study conducted in Figure 9. 


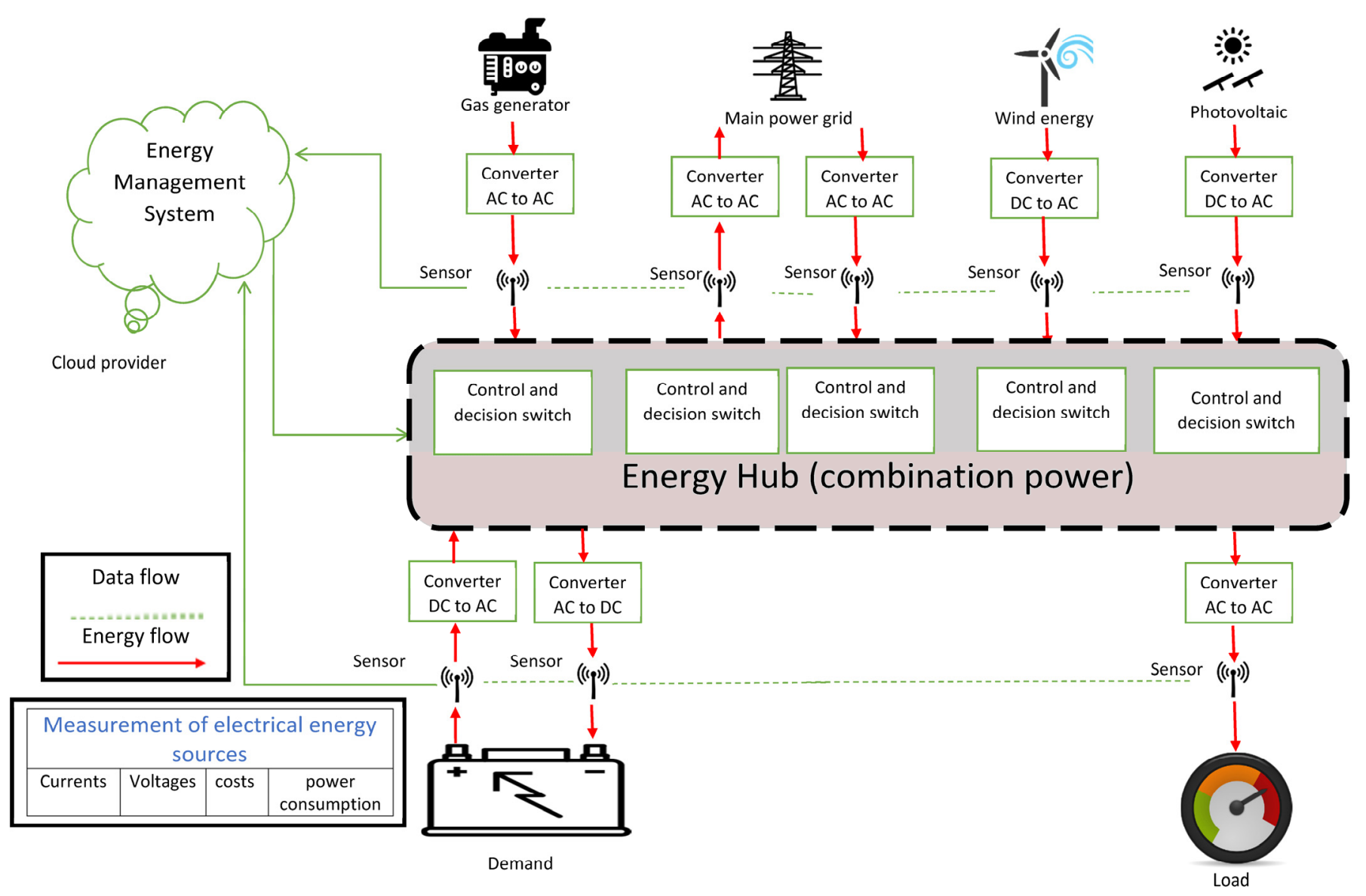

Figure 9. The framework system model for energy sustainability.

\section{Conclusions}

The study summarized the recently published literature that focuses on methods to reduce power consumption and costs. Furthermore, the recent literature discussed using cloud computing to store EMSs and managing them intelligently. Furthermore, it discussed how a well-maintained system of power mixing (power used to charge the batteries) can lead to better environmental results by reducing the carbon footprint. Furthermore, it discussed the recent literature that used cloud computing to store EMSs and manage them intelligently. As a result of this extensive literature review, the researcher proposed a final chart of the model that will consider three aspects: battery management, RE, and cloud computing, which will be the main contribution of the future study conducted by the researcher.

Author Contributions: Drafted the original manuscript, conceptualization, literature analysis, A.H.A.A.-J.; Conceptualization and methodology, Y.I.A.M.; Investigation and supervision and validation R.S. and Z.A.A.A. All authors have read and agreed to the published version of the manuscript.

Funding: This research was funded by the Malaysian Fundamental Research Grant Scheme (FRGS) under the code PP-FTSM-2021 and TAP-K01149.

Institutional Review Board Statement: Not applicable.

Informed Consent Statement: Not applicable.

Data Availability Statement: Not applicable.

Acknowledgments: The authors gratefully acknowledge the financial support of the Laboratory of Faculty of Information Science and Technology, Universiti Kebangsaan Malaysia, Malaysia and University of Fallujah, Iraq. 
Conflicts of Interest: The authors declare no conflict of interest.

Ethics and Permission to Participate: This manuscript has not been previously released and is not now under consideration by any journal for publication.

\section{Abbreviations}

In this review, the following abbreviations are used:

\begin{tabular}{|c|c|}
\hline Abbreviations & The Details \\
\hline VPPs & Virtual Power Plants \\
\hline DC & Direct Current \\
\hline CDE & Carbon Dioxide Emissions \\
\hline RE & Renewable Energy \\
\hline USDOE & United States Department of Energy \\
\hline SG & Smart Grid \\
\hline SGs & Smart Grids \\
\hline SES & Smart Energy Systems \\
\hline AI & Artificial Intelligence \\
\hline DR & Demand Response \\
\hline PS & Power Supply \\
\hline DER & Distributed Energy Resource \\
\hline MT & Microgrid Trading \\
\hline DDoS & Distributed Denial of Service \\
\hline CPU's & Central Processing Units \\
\hline SPM & Static Power Management \\
\hline DPM & Dynamic Power Management \\
\hline DPC & Dynamic Power Consumption \\
\hline C & Coulomb \\
\hline A & Amperes \\
\hline $\mathrm{V}$ & Volts \\
\hline W & Watts \\
\hline WH & Watt-Hours \\
\hline GA & Genetic Algorithm \\
\hline PSO & Particle Swarm Optimization \\
\hline FL & Fuzzy Logic \\
\hline MOA & Metaheuristic Optimization Algorithms \\
\hline SoC & State of Charge \\
\hline KW & kilowatt \\
\hline GPR & Gaussian Process Regression \\
\hline GIESBs & Grid-Integrated Energy Storage Batteries \\
\hline PVs & Photo Voltic's \\
\hline WTs & Wind Turbines \\
\hline EBMS & Electric Bus Management System \\
\hline ANNs & Artificial Neural Networks \\
\hline EMS & Energy Management System \\
\hline HMG & Hybrid Micro-Grid \\
\hline MOPSO & Multi-Objective Particle Swarm Optimization \\
\hline PMP & Pontryagin's Minimum Principle \\
\hline MEET & Maximum Efficiency Tracking \\
\hline FAFC & First Access First Charge \\
\hline MDP & Markov Decision Process \\
\hline HEMS & Home energy management system \\
\hline SHEMS & Smart Home Energy Management System \\
\hline BMS & Battery Management system \\
\hline MWs & Mega Watts \\
\hline
\end{tabular}




$\begin{array}{ll}\text { ETMCTSA } & \text { Energy-Performance Trade-off Multi-Resource Cloud Task Scheduling Algorithm } \\ \text { IT } & \text { Information Technology } \\ \text { VMs } & \text { Virtual Machines } \\ \text { TWh } & \text { Tera Watt-hours } \\ \text { HV } & \text { High Voltage } \\ \text { MV } & \text { Medium Voltage } \\ \text { SCADA } & \text { Supervisory Control and Data Acquisition } \\ \text { AMI } & \text { Advanced Metering Infrastructure } \\ \text { ELM } & \text { Extreme Learning Machine } \\ \text { SCVS } & \text { Sorting and Cumulative Voltage Summation } \\ \text { EVCS } & \text { Electric Vehicle Charging Station } \\ \text { EPS } & \text { Electric Power System } \\ \text { EFS } & \text { Effective Feature Set } \\ \text { PMU } & \text { Phasor Measurement Units } \\ \text { WAMS } & \text { Wide Area Monitoring System } \\ \text { TSA } & \text { Transient Stability Analysis } \\ \text { CVM } & \text { Core Vector Machine } \\ \text { BAS } & \text { Building Automation Systems } \\ \text { HVAC } & \text { Heating, Ventilation, and Air Conditioning } \\ \text { PHM } & \text { Proportional Hazards Model } \\ \text { PQ } & \text { Power Quality } \\ \text { LV } & \text { Little Voltage } \\ \text { RNN } & \text { Regular Neural Network } \\ \text { NILM } & \text { Non-Intrusive Load Monitoring } \\ \text { NTL } & \text { Non-Technical Lack } \\ \text { LLC } & \text { Limited Liability Company } \\ \text { SVM } & \text { Suggest Vector Machine } \\ \text { DT } & \text { Decision Tree } \\ \text { SaaS } & \text { Service as a Service } \\ \text { ICT } & \text { Information and Communication Technology } \\ \text { PAR } & \text { Peak-to-Average Ratio } \\ \text { WECS } & \text { Wind Energy Conversion System } \\ \text { DCEP } & \text { Data Center Energy Productivity } \\ \text { TOU } & \text { Time-Of-Use } \\ \text { MASs } & \text { Multi-Agent Systems } \\ \text { GHGs } & \text { Green House Gases } \\ \text { IoE } & \text { Internet of Energy } \\ \text { IaaS } & \text { Infrastructure as a Service } \\ \text { PaaS } & \text { Platform as a Service } \\ \text { LMA } & \text { Levenberg-Marquardt Algorithm } \\ \text { TRRA } & \text { Trust-Region Reflective Algorithm } \\ \text { PUE } & \text { Power Use Effectiveness } \\ \text { RESs } & \text { Renewable Energy Sources } \\ \text { EFS } & \text { Effective Feature Set } \\ \text { BESSs } & \text { Battery energy storage systems } \\ \text { EEH } & \text { Energy-Efficient Hybrid } \\ \text { ARBC } & \text { Adaptive Resonant Beam Charging } \\ & \end{array}$

\section{References}

1. Lin, B.; Ahmad, I. Technical change, inter-factor and inter-fuel substitution possibilities in Pakistan: A trans-log production function approach. J. Clean. Prod. 2016, 126, 537-549. [CrossRef]

2. Sun, C.C.; Hahn, A.; Liu, C.C. Cyber security of a power grid: State-of-the-art. Int. J. Electr. Power Energy Syst. 2018, 99, 45-56. [CrossRef]

3. Meri, A.; Hasan, M.K.; Satar, N.S.M. Success factors affecting the healthcare professionals to utilize cloud computing services. Asia-Pac. J. Inf. Technol. Multimed. 2017, 6, 31-42. [CrossRef] 
4. Bohani, F.A.; Yahya, S.R.; Abdullah, S.N.H.S. Microgrid Communication and Security: State-Of-The-Art and Future Directions. J. Integr. Adv. Eng. 2021, 1, 37-52. [CrossRef]

5. Begovic, M.M. System protection. In Power System Stability and Control, 3rd ed.; CRC Press: Boca Raton, FL, USA, 2017; pp. 4-1-4-10. [CrossRef]

6. Hannan, M.A.; Tan, S.Y.; Al-Shetwi, A.Q.; Jern, K.P.; Begum, R.A. Optimized controller for renewable energy sources integration into microgrid: Functions, constraints and suggestions. J. Clean. Prod. 2020, 256, 120419. [CrossRef]

7. Zhang, S.; Luo, X.; Litvinov, E. Serverless computing for cloud-based power grid emergency generation dispatch. Int. J. Electr. Power Energy Syst. 2021, 124, 106366. [CrossRef]

8. Haque, A.N.M.M.; Ibn Saif, A.U.N.; Nguyen, P.H.; Torbaghan, S.S. Exploration of dispatch model integrating wind generators and electric vehicles. Appl. Energy 2016, 183, 1441-1451. [CrossRef]

9. Zaman, K.; el Moemen, M.A. Energy consumption, carbon dioxide emissions and economic development: Evaluating alternative and plausible environmental hypothesis for sustainable growth. Renew. Sustain. Energy Rev. 2017, 74, 1119-1130. [CrossRef]

10. Cai, H.; Xu, B.; Jiang, L.; Vasilakos, A.V. IoT-Based Big Data Storage Systems in Cloud Computing: Perspectives and Challenges. IEEE Internet Things J. 2017, 4, 75-87. [CrossRef]

11. Bogdanov, D.; Farfan, J.; Sadovskaia, K.; Aghahosseini, A.; Child, M.; Gulagi, A.; Oyewo, A.S.; de Souza Noel Simas Barbosa, L.; Breyer, C. Radical transformation pathway towards sustainable electricity via evolutionary steps. Nat. Commun. 2019, $10,1077$. [CrossRef]

12. Clack, C.T.M.; Qvist, S.A.; Apt, J.; Bazilian, M.; Brandt, A.R.; Caldeira, K.; Davis, S.J.; Diakov, V.; Handschy, M.A.; Hines, P.D.H.; et al. Evaluation of a proposal for reliable low-cost grid power with $100 \%$ wind, water, and solar. Proc. Natl. Acad. Sci. USA 2017, 114, 6722-6727. [CrossRef]

13. Parag, Y.; Sovacool, B.K. Electricity market design for the prosumer era. Nat. Energy 2016, 1, 16032. [CrossRef]

14. Xu, F.; Wu, W.; Zhao, F.; Zhou, Y.; Wang, Y.; Wu, R.; Zhang, T.; Wen, Y.; Fan, Y.; Jiang, S. A micro-market module design for university demand-side management using self-crossover genetic algorithms. Appl. Energy 2019, 252, 113456. [CrossRef]

15. Chen, K.; Lin, J.; Song, Y. Trading strategy optimization for a prosumer in continuous double auction-based peer-to-peer market: A prediction-integration model. Appl. Energy 2019, 242, 1121-1133. [CrossRef]

16. Song, Y.; Ding, Y.; Siano, P.; Meinrenken, C.; Zheng, M.; Strbac, G. Optimization methods and advanced applications for smart energy systems considering grid-interactive demand response. Appl. Energy 2020, 259, 113994. [CrossRef]

17. Li, W.; Assaad, M. Matrix Exponential Learning Schemes with Low Informational Exchange. IEEE Trans. Signal Process. 2019, 67, 3140-3153. [CrossRef]

18. Li, W.; Rentemeister, M.; Badeda, J.; Jöst, D.; Schulte, D.; Sauer, D.U. Digital twin for battery systems: Cloud battery management system with online state-of-charge and state-of-health estimation. J. Energy Storage 2020, 30, 101557. [CrossRef]

19. Dai, H.; Jiang, B.; Hu, X.; Lin, X.; Wei, X.; Pecht, M. Advanced battery management strategies for a sustainable energy future: Multilayer design concepts and research trends. Renew. Sustain. Energy Rev. 2021, 138, 110480. [CrossRef]

20. Ling, Z.; Luo, M.; Song, J.; Zhang, W.; Zhang, Z.; Fang, X. A fast-heat battery system using the heat released from detonated supercooled phase change materials. Energy 2021, 219, 119496. [CrossRef]

21. Sharma, S.; Kotturu, P.K.; Narooka, P.C. Implication of IoT Components and Energy Management Monitoring. Swarm Intell. Optim. 2020, 49-65. [CrossRef]

22. Zhang, Q.; Fang, W.; Xiong, M.; Liu, Q.; Wu, J.; Xia, P. Adaptive Resonant Beam Charging for Intelligent Wireless Power Transfer. IEEE Internet Things J. 2019, 6, 1160-1172. [CrossRef]

23. Mehrjerdi, H. Resilience oriented vehicle-to-home operation based on battery swapping mechanism. Energy 2021, $218,119528$. [CrossRef]

24. Li, S.; Li, J.; Wang, H. Big data driven Lithium-ion battery modeling method: A cyber-physical system approach. In Proceedings of the 2019 IEEE International Conference on Industrial Cyber Physical Systems (ICPS), Taipei, Taiwan, 6-9 May 2019; pp. 161-166. [CrossRef]

25. Kouache, I.; Sebaa, M.; Bey, M.; Allaoui, T.; Denai, M. A new approach to demand response in a microgrid based on coordination control between smart meter and distributed superconducting magnetic energy storage unit. J. Energy Storage 2020, 32, 101748. [CrossRef]

26. Piovesan, N.; Fernandez Gambin, A.; Miozzo, M.; Rossi, M.; Dini, P. Energy sustainable paradigms and methods for future mobile networks: A survey. Comput. Commun. 2018, 119, 101-117. [CrossRef]

27. Ali, A.; Mahmoud, K.; Lehtonen, M. Maximizing Hosting Capacity of Uncertain Photovoltaics by Coordinated Management of OLTC, VAr Sources and Stochastic EVs. Int. J. Electr. Power Energy Syst. 2021, 127, 106627. [CrossRef]

28. Faisal, M.; Hannan, M.A.; Ker, P.J.; Rahman, M.S.A.; Begum, R.A.; Mahlia, T.M.I. Particle swarm optimised fuzzy controller for charging-discharging and scheduling of battery energy storage system in MG applications. Energy Rep. 2020, 6, 215-228. [CrossRef]

29. Abdulmula, A.; Sopian, K.; Haw, L.C.; Fazlizan, A. Performance evaluation of standalone double axis solar tracking system with maximum light detection MLD for telecommunication towers in Malaysia. Int. J. Power Electron. Drive Syst. 2019, 10, 444-453. [CrossRef]

30. Kasturi, K.; Nayak, C.K.; Nayak, M.R. Analysis of photovoltaic \& battery energy storage system impacts on electric distribution system efficacy. Int. J. Electr. Eng. Inform. 2020, 12, 1001-1015. [CrossRef] 
31. Hannan, M.A.; Islam, N.N.; Mohamed, A.; Lipu, M.S.H.; Ker, P.J.; Rashid, M.M.; Shareef, H. Artificial intelligent based damping controller optimization for the multi-machine power system: A review. IEEE Access 2018, 6, 39574-39594. [CrossRef]

32. Choudhary, A.; Govil, M.C.; Singh, G.; Awasthi, L.K.; Pilli, E.S.; Kapil, D. A critical survey of live virtual machine migration techniques. J. Cloud Comput. 2017, 6, 23. [CrossRef]

33. Nan, S.; Zhou, M.; Li, G. Optimal residential community demand response scheduling in smart grid. Appl. Energy 2018, 210, 1280-1289. [CrossRef]

34. Ben Ghorbel, M.; Hamdaoui, B.; Guizani, M.; Mohamed, A. Long-Term Power Procurement Scheduling Method for Smart-Grid Powered Communication Systems. IEEE Trans. Wirel. Commun. 2018, 17, 2882-2892. [CrossRef]

35. Du, Y.F.; Jiang, L.; Li, Y.; Wu, Q. A robust optimization approach for demand side scheduling considering uncertainty of manually operated appliances. IEEE Trans. Smart Grid 2018, 9, 743-755. [CrossRef]

36. Rahman, A.A.A.; Osman, M.S.; Ng, R.; Abdullah, S.; Rahman, M.A.A.; Mohamad, E.; Rahman, A.A. Integration of simulation technologies with physical system of reconfigurable material handling. J. Adv. Manuf. Technol. 2018, 12, $139-152$.

37. Rehmani, M.H.; Reisslein, M.; Rachedi, A.; Erol-Kantarci, M.; Radenkovic, M. Integrating Renewable Energy Resources into the Smart Grid: Recent Developments in Information and Communication Technologies. IEEE Trans. Ind. Inform. 2018, 14, $2814-2825$. [CrossRef]

38. Hanif, I. Impact of fossil fuels energy consumption, energy policies, and urban sprawl on carbon emissions in East Asia and the Pacific: A panel investigation. Energy Strategy Rev. 2018, 21, 16-24. [CrossRef]

39. Kim, H.; Kim, Y.J.; Yang, K.; Thottan, M. Cloud-based demand response for smart grid: Architecture and distributed algorithms. In Proceedings of the 2011 IEEE International Conference on Smart Grid Communications (SmartGridComm), Brussels, Belgium, 17-20 October 2011; pp. 398-403. [CrossRef]

40. Menshari, A.; Salehi, G.; Ghiamy, M. A Novel Technique for Multiple Microgrids Planning by Considering Demand Response Programming and Social Welfare Enhancement in Power Market. Rev. Publicando 2018. Available online: https://www. revistapublicando.org/revista/index.php/crv/article/view/1381 (accessed on 16 August 2021).

41. Yang, C.T.; Chen, W.S.; Huang, K.L.; Liu, J.C.; Hsu, W.H.; Hsu, C.H. Implementation of smart power management and service system on cloud computing. In Proceedings of the IEEE 9th International Conference on Ubiquitous Intelligence and Computing and IEEE 9th International Conference on Autonomic and Trusted Computing, Fukuoka, Japan, 4-7 September 2012; pp. 924-929. [CrossRef]

42. Yaghmaee, M.H.; Moghaddassian, M.; Leon-Garcia, A. Autonomous Two-Tier Cloud-Based Demand Side Management Approach with Microgrid. IEEE Trans. Ind. Inform. 2017, 13, 1109-1120. [CrossRef]

43. Pacheco, L.A.B.; Gondim, J.J.C.; Barreto, P.A.S.; Alchieri, E. Evaluation of distributed denial of service threat in the internet of things. In Proceedings of the 2016 IEEE 15th International Symposium on Network Computing and Applications (NCA), Cambridge, MA, USA, 31 October-2 November 2016; pp. 89-92. [CrossRef]

44. Tahir, M.F.; Haoyong, C.; Khan, A.; Javed, M.S.; Laraik, N.A.; Mehmood, K. Optimizing size of variable renewable energy sources by incorporating energy storage and demand response. IEEE Access 2019, 7, 103115-103126. [CrossRef]

45. Munshi, A.A.; Mohamed, Y.A.R.I. Big data framework for analytics in smart grids. Electr. Power Syst. Res. 2017, 151, 369-380. [CrossRef]

46. Priya, E.S.; Suseendran, G. Cloud computing and big data: A comprehensive analysis. J. Crit. Rev. 2020, 7, 185-189. [CrossRef]

47. Islam, M.; Reza, S. The Rise of Big Data and Cloud Computing. Internet Things Cloud Comput. 2019, 7, 45. [CrossRef]

48. Antunes, C.H.; Soares, A.; Gomes, Á. An energy management system for residential demand response based on multiobjective optimization. In Proceedings of the 2016 IEEE Smart Energy Grid Engineering (SEGE), Oshawa, ON, Canada, 21-24 August 2016; pp. 90-94. [CrossRef]

49. Martinez, C.M.; Hu, X.; Cao, D.; Velenis, E.; Gao, B.; Wellers, M. Energy Management in Plug-in Hybrid Electric Vehicles: Recent Progress and a Connected Vehicles Perspective. IEEE Trans. Veh. Technol. 2017, 66, 4534-4549. [CrossRef]

50. Asadinejad, A.; Tomsovic, K. Optimal use of incentive and price based demand response to reduce costs and price volatility. Electr. Power Syst. Res. 2017, 144, 215-223. [CrossRef]

51. Jordehi, A.R. Optimisation of demand response in electric power systems, a review. Renew. Sustain. Energy Rev. 2019, 103, 308-319. [CrossRef]

52. Rieger, A.; Thummert, R.; Fridgen, G.; Kahlen, M.; Ketter, W. Estimating the benefits of cooperation in a residential microgrid: A data-driven approach. Appl. Energy 2016, 180, 130-141. [CrossRef]

53. Siano, P.; Sarno, D. Assessing the benefits of residential demand response in a real time distribution energy market. Appl. Energy 2016, 161, 533-551. [CrossRef]

54. Marzband, M.; Alavi, H.; Ghazimirsaeid, S.S.; Uppal, H.; Fernando, T. Optimal energy management system based on stochastic approach for a home Microgrid with integrated responsive load demand and energy storage. Sustain. Cities Soc. 2017, 28, 256-264. [CrossRef]

55. Amrollahi, M.H.; Bathaee, S.M.T. Techno-economic optimization of hybrid photovoltaic/wind generation together with energy storage system in a stand-alone micro-grid subjected to demand response. Appl. Energy 2017, 202, 66-77. [CrossRef]

56. Korkas, C.D.; Baldi, S.; Michailidis, I.; Kosmatopoulos, E.B. Occupancy-based demand response and thermal comfort optimization in microgrids with renewable energy sources and energy storage. Appl. Energy 2016, 163, 93-104. [CrossRef] 
57. Honarmand, M.E.; Hosseinnezhad, V.; Ghazizadeh, M.S.; Wang, F.; Siano, P. A peak-load-reduction-based procedure to manage distribution network expansion by applying process-oriented costing of incoming components. Energy 2019, 186, 115852. [CrossRef]

58. Huang, W.; Zhang, N.; Kang, C.; Li, M.; Huo, M. From demand response to integrated demand response: Review and pro-spect of research and application. Prot. Control. Mod. Power Syst. 2019, 4. [CrossRef]

59. Robert, F.C.; Sisodia, G.S.; Gopalan, S. A critical review on the utilization of storage and demand response for the imple-mentation of renewable energy microgrids. Sustain. Cities Soc. 2018, 40, 735-745. [CrossRef]

60. U.S. Energy Information Administration (EIA). International Energy Outlook 2016; 2016; Volume 0484. Available online: http: //www.eia.gov/forecasts/ieo/ (accessed on 16 August 2021).

61. Kober, T.; Schiffer, H.W.; Densing, M.; Panos, E. Global energy perspectives to 2060—WEC's World Energy Scenarios 2019. Energy Strategy Rev. 2020, 31, 100523. [CrossRef]

62. Ahmad, T.; Zhang, D. A critical review of comparative global historical energy consumption and future demand: The story told so far. Energy Rep. 2020, 6, 1973-1991. [CrossRef]

63. Ogheneovo Johnson, D. Issues of Power Quality in Electrical Systems. Int. J. Energy Power Eng. 2016, 5, 148. [CrossRef]

64. Elshrkawey, M.; Elsherif, S.M.; Wahed, M.E. An Enhancement Approach for Reducing the Energy Consumption in Wireless Sensor Networks. J. King Saud Univ.-Comput. Inf. Sci. 2018, 30, 259-267. [CrossRef]

65. Mohammed, M.A.; Mohammed, I.A.; Hasan, R.A.; Tapus, N.; Ali, A.H.; Hammood, O.A. Green Energy Sources: Issues and Challenges. In Proceedings of the 2019 18th RoEduNet Conference: Networking in Education and Research (RoEduNet), Galati, Romania, 10-12 October 2019. [CrossRef]

66. Valentini, G.L.; Lassonde, W.; Khan, S.U.; Min-Allah, N.; Madani, S.A.; Li, J.; Zhang, L.; Wang, L.; Ghani, N.; Kolodziej, J.; et al. An overview of energy efficiency techniques in cluster computing systems. Clust. Comput. 2013, 16, 3-15. [CrossRef]

67. Mondal, H.K.; Gade, S.H.; Kishore, R.; Kaushik, S.; Deb, S. Power efficient router architecture for wireless Network-on-Chip. In Proceedings of the 2016 17th International Symposium on Quality Electronic Design (ISQED), Santa Clara, CA, USA, 15-16 March 2016; pp. 227-233. [CrossRef]

68. Al-Dulaimy, A.; Itani, W.; Zekri, A.; Zantout, R. Power management in virtualized data centers: State of the art. J. Cloud Comput. 2016, 5, 6. [CrossRef]

69. Fountoulakis, E.; Pappas, N.; Ephremides, A. Dynamic Power Control for Time-Critical Networking with Heterogeneous Traffic. 2020. Available online: http:/ / arxiv.org/abs/2011.04448 (accessed on 16 August 2021).

70. Holz, C.; Pusch, A. Do powerbanks deliver what they advertise? Measuring voltage, current, power, energy and charge of powerbanks with an Arduino. Phys. Educ. 2020, 55, 025013. [CrossRef]

71. Cheng, C.H.; Bai, Y.W. An automatically peak-shift control design for charging and discharging of the battery in an ultrabook. IEICE Trans. Inf. Syst. 2016, E99D, 1108-1116. [CrossRef]

72. Chen, Z.; Shu, X.; Sun, M.; Shen, J.; Xiao, R. Charging strategy design of lithium-ion batteries for energy loss minimization based on minimum principle. In Proceedings of the 2017 IEEE Transportation Electrification Conference and Expo, Asia-Pacific (ITEC Asia-Pacific), Harbin, China, 7-10 August 2017; pp. 1-6. [CrossRef]

73. Hadian, E.; Akbari, H.; Farzinfar, M.; Saeed, S. Optimal allocation of electric vehicle charging stations with adopted smart charging/discharging schedule. IEEE Access 2020, 8, 196908-196919. [CrossRef]

74. Vallejo-Huanga, D.; Proaño, J.; Morillo, P.; Ortega, H. Fault-tolerant model based on fuzzy control for mobile devices. Commun. Comput. Inf. Sci. 2019, 895, 488-499. [CrossRef]

75. Qin, P.; Sun, J.; Yang, X.; Wang, Q. Battery thermal management system based on the forced-air convection: A review. eTransportation 2021, 7, 100097. [CrossRef]

76. Wu, B.; Widanage, W.D.; Yang, S.; Liu, X. Battery digital twins: Perspectives on the fusion of models, data and artificial intelligence for smart battery management systems. Energy AI 2020, 1, 100016. [CrossRef]

77. Gharehpetian, G.B.; Agah, S.M.M. Distributed Generation Systems: Design, Operation and Grid Integration; Butterworth-Heinemann: Oxford, UK, 2017.

78. Zheng, Y.; He, Y.B.; Qian, K.; Li, B.; Wang, X.; Li, J.; Miao, C.; Kang, F. Effects of state of charge on the degradation of LiFePO4/graphite batteries during accelerated storage test. J. Alloys Compd. 2015, 639, 406-414. [CrossRef]

79. Hussein, W.A.; Abdullah, S.N.H.S.; Sahran, S. The Patch-Levy-Based Bees Algorithm Applied to Dynamic Optimization Problems. Discret. Dyn. Nat. Soc. 2017, 2017, 5678393. [CrossRef]

80. Das, A.; Ni, Z. A computationally efficient optimization approach for battery systems in islanded microgrid. IEEE Trans. Smart Grid 2018, 9, 6489-6499. [CrossRef]

81. Lipu, M.S.H.; Hannan, M.A.; Hussain, A.; Ayob, A.; Saad, M.H.M.; Muttaqi, K.M. State of charge estimation in lithium-ion batteries: A neural network optimization approach. Electronics 2020, 9, 1546. [CrossRef]

82. Cuadras, A.; Miró, P.; Ovejas, V.J.; Estrany, F. Entropy generation model to estimate battery ageing. J. Energy Storage 2020, 32. [CrossRef]

83. Lin, Q.; Wang, J.; Xiong, R.; Shen, W.; He, H. Towards a smarter battery management system: A critical review on optimal charging methods of lithium ion batteries. Energy 2019, 183, 220-234. [CrossRef]

84. Niri, M.F.; Bui, T.M.N.; Dinh, T.Q.; Hosseinzadeh, E.; Yu, T.F.; Marco, J. Remaining energy estimation for lithium-ion batteries via Gaussian mixture and Markov models for future load prediction. J. Energy Storage 2020, 28, 101271. [CrossRef] 
85. Xiong, R.; Pan, Y.; Shen, W.; Li, H.; Sun, F. Lithium-ion battery aging mechanisms and diagnosis method for automotive applications: Recent advances and perspectives. Renew. Sustain. Energy Rev. 2020, 131, 110048. [CrossRef]

86. Sahinoglu, G.O.; Pajovic, M.; Sahinoglu, Z.; Wang, Y.; Orlik, P.V.; Wada, T. Battery State-of-Charge Estimation Based on Regular/Recurrent Gaussian Process Regression. IEEE Trans. Ind. Electron. 2018, 65, 4311-4321. [CrossRef]

87. Aravindan, R.; Thirugnanasambantham, K.G.; Kumar, T.A.; Viswaraj, M.N.; Suthershan, K. A novel integration of battery system in automotive vehicle. Proc. Int. Conf. Recent Trends Mech. Mater. Eng. Icrtmme 2019 2020, 2283, 020051. [CrossRef]

88. Boulmrharj, S.; NaitMalek, Y.; Elmouatamid, A.; Bakhouya, M.; Ouladsine, R.; Zine-Dine, K.; Khanidar, M.; Siniti, M. Battery characterization and dimensioning approaches for micro-grid systems. Energies 2019, 12, 1305. [CrossRef]

89. Campana, P.E.; Cioccolanti, L.; François, B.; Jurasz, J.; Zhang, Y.; Varini, M.; Stridh, B.; Yan, J. Li-ion batteries for peak shaving, price arbitrage, and photovoltaic self-consumption in commercial buildings: A Monte Carlo Analysis. Energy Convers. Manag. 2021, 234, 113889. [CrossRef]

90. Al Essa, M.J.M. Power management of grid-integrated energy storage batteries with intermittent renewables. J. Energy Storage 2020, 31, 101762. [CrossRef]

91. Moussa, S.; Ghorbal, M.J.B.; Slama-Belkhodja, I. Bus voltage level choice for standalone residential DC nanogrid. Sustain. Cities Soc. 2019, 46, 101431. [CrossRef]

92. Al-Ogaili, A.S.; Ramasamy, A.; Hashim, T.J.T.; Al-Masri, A.N.; Hoon, Y.; Jebur, M.N.; Verayiah, R.; Marsadek, M. Estimation of the energy consumption of battery driven electric buses by integrating digital elevation and longitudinal dynamic models: Malaysia as a case study. Appl. Energy 2020, 280, 115873. [CrossRef]

93. Masih, A.; Verma, H.K. Renewable Hybrid Battery Energy Management System Using ANN Controller. 2020. Available online: https:/ / easychair.org/publications/preprint_download/sMG2 (accessed on 16 August 2021).

94. Igbinovia, F.O.; Krupka, J.; Hajek, P.; Muller, Z.; Tlusty, J. Electricity storage in internet of renewable energy (IoRE) domain for sustainable smart cities. In Proceedings of the 2020 21st International Scientific Conference on Electric Power Engineering (EPE), Prague, Czech Republic, 19-21 October 2020. [CrossRef]

95. Lilis, G.; Conus, G.; Asadi, N.; Kayal, M. Towards the next generation of intelligent building: An assessment study of current automation and future IoT based systems with a proposal for transitional design. Sustain. Cities Soc. 2017, 28, 473-481. [CrossRef]

96. Miglani, A.; Kumar, N.; Chamola, V.; Zeadally, S. Blockchain for Internet of Energy management: Review, solutions, and challenges. Comput. Commun. 2020, 151, 395-418. [CrossRef]

97. Gunasekaran, M.; Ismail, H.M.; Chokkalingam, B.; Mihet-Popa, L.; Padmanaban, S. Energy management strategy for rural communities' DC micro grid power system structure with maximum penetration of renewable energy sources. Appl. Sci. 2018, 8, 585. [CrossRef]

98. Indragandhi, V.; Logesh, R.; Subramaniyaswamy, V.; Vijayakumar, V.; Siarry, P.; Uden, L. Multi-objective optimization and energy management in renewable based AC/DC microgrid. Comput. Electr. Eng. 2018, 70, 179-198. [CrossRef]

99. DeSando, M. Universal Programmable Battery Charger with Optional Battery Management System; California Polytechnic State University: San Luis Obispo, CA, USA, 2015.

100. Setore, Y.D. Modeling and Design of a Level-2 Onboard Lithium-ion Battery Charging System for ECADO Four-Wheel Electric Vehicle; Adama Science and Technology University: Adama, Ethiopia, 2020.

101. Edpuganti, A.; Khadkikar, V.; Zeineldin, H.; el Moursi, M.S.; al Hosani, M. Comparison of Peak Power Tracking Based Electric Power System Architectures for CubeSats. IEEE Trans. Ind. Appl. 2021, 57, 2758-2768. [CrossRef]

102. Choi, J.Y.; Choi, I.S.; Ahn, G.H.; Won, D.J. Advanced power sharing method to improve the energy efficiency of multiple battery energy storages system. IEEE Trans. Smart Grid 2018, 9, 1292-1300. [CrossRef]

103. Mansour, O.M.A.A. Determining the Power and Energy Capacity of a Battery Energy Storage System Utilizing a Smoothing Feeder Preeder Profile too Accommodate High Photo Accommodate High Photovoltaic Penetration on a Distribution Feeder; Portland State University: Portland, OR, USA, 2016.

104. Guo, Y.; Yang, Z.; Liu, K.; Zhang, Y.; Feng, W. A compact and optimized neural network approach for battery state-of-charge estimation of energy storage system. Energy 2021, 219, 119529. [CrossRef]

105. Zavos, I. Design and Modeling of Switching Battery Management System for Solar-Powered Storage Installations; Eindhoven University of Technology: Eindhoven, The Netherlands, 2020.

106. Li, Y.; Guo, H.; Qi, F.; Guo, Z.; Li, M.; Tjernberg, L.B. Investigation on liquid cold plate thermal management system with heat pipes for LiFePO4 battery pack in electric vehicles. Appl. Therm. Eng. 2021, 185, 116382. [CrossRef]

107. Rogers, D.J.; Aslett, L.J.M.; Troffaes, M.C.M. Modelling of modular battery systems under cell capacity variation and degradation. Appl. Energy 2021, 283, 116360. [CrossRef]

108. Asgher, U.; Babar Rasheed, M.; Al-Sumaiti, A.S.; Ur-Rahman, A.; Ali, I.; Alzaidi, A.; Alamri, A. Smart energy optimization using heuristic algorithm in smart grid with integration of solar energy sources. Energies 2018, 11, 3494. [CrossRef]

109. Kure, E.H.H.; Maharjan, S.; Gjessing, S.; Zhang, Y. Optimal battery size for a green base station in a smart grid with a renewable energy source. In Proceedings of the 2017 IEEE International Conference on Smart Grid Communications (SmartGridComm), Dresden, Germany, 23-27 October 2017; pp. 115-121. [CrossRef]

110. Boulmrharj, S.; Ouladsine, R.; NaitMalek, Y.; Bakhouya, M.; Zine-dine, K.; Khaidar, M.; Siniti, M. Online battery state-of-charge estimation methods in micro-grid systems. J. Energy Storage 2020, 30, 101518. [CrossRef] 
111. Matthiesen, B.; Zappone, A.; Jorswieck, E.A.; Debbah, M. Deep learning for real-time energy-efficient power control in mobile networks. In Proceedings of the 2019 IEEE 20th International Workshop on Signal Processing Advances in Wireless Communications (SPAWC), Cannes, France, 2-5 July 2019; pp. 1-5. [CrossRef]

112. Duman, A.C.; Erden, H.S.; Gönül, Ö.; Güler, Ö. A home energy management system with an integrated smart thermostat for demand response in smart grids. Sustain. Cities Soc. 2021, 65, 102639. [CrossRef]

113. Jayaprakash, M.; Kavitha, D.; Ramkumar, M.S.; Balachander, K.; Krishnan, M.S. Achieving efficient and secure data acquisition for cloud-supported internet of things in grid connected solar, wind and battery systems. Math. Comput. For. Nat. Resour. Sci. 2019, 11, 144-155.

114. Alarifi, A.; Dubey, K.; Amoon, M.; Altameem, T.; Abd El-Samie, F.E.; Altameem, A.; Sharma, S.C.; Nasr, A.A. Energy-Efficient Hybrid Framework for Green Cloud Computing. IEEE Access 2020, 8, 115356-115369. [CrossRef]

115. Pusceddu, E.; Zakeri, B.; Gissey, G.C. Synergies between energy arbitrage and fast frequency response for battery energy storage systems. Applied Energy 2021, 283, 116274. [CrossRef]

116. Vilsen, S.B.; Stroe, D.-I. Battery state-of-health modelling by multiple linear regression. J. Clean. Prod. 2021, 290, 125700. [CrossRef]

117. Bitzer, B.; Gebretsadik, E.S. Ensuring future clean electrical energy supply through cloud computing. In Proceedings of the 2015 International Conference on Clean Electrical Power (ICCEP), Taormina, Italy, 16-18 June 2015; pp. 155-159. [CrossRef]

118. Yang, S.; He, R.; Zhang, Z.; Cao, Y.; Gao, X.; Liu, X. CHAIN: Cyber Hierarchy and Interactional Network Enabling Digital Solution for Battery Full-Lifespan Management. Matter 2020, 3, 27-41. [CrossRef]

119. Sui, Y.; Yao, F. Application of Embedded Network Distributed Network in Student Physical Health Management Platform. Microprocess. Microsyst. 2021, 80, 103576. [CrossRef]

120. Teng, J.H.; Luan, S.W.; Lee, D.J.; Huang, Y.Q. Optimal charging/discharging scheduling of battery storage systems for distribution systems interconnected with sizeable PV generation systems. IEEE Trans. Power Syst. 2013, 28, 1425-1433. [CrossRef]

121. Hernández, J.C.; Ruiz-Rodriguez, F.J.; Jurado, F. Technical impact of photovoltaic-distributed generation on radial distribution systems: Stochastic simulations for a feeder in Spain. Int. J. Electr. Power Energy Syst. 2013, 50, 25-32. [CrossRef]

122. Aktas, A.; Erhan, K.; Ozdemir, S.; Ozdemir, E. Experimental investigation of a new smart energy management algorithm for a hybrid energy storage system in smart grid applications. Electr. Power Syst. Res. 2017, 144, 185-196. [CrossRef]

123. Howell, S.; Rezgui, Y.; Hippolyte, J.L.; Jayan, B.; Li, H. Towards the next generation of smart grids: Semantic and holonic multi-agent management of distributed energy resources. Renew. Sustain. Energy Rev. 2017, 77, 193-214. [CrossRef]

124. Shawon, M.H.; Muyeen, S.M.; Ghosh, A.; Islam, S.M.; Baptista, M.S. Multi-agent systems in ICT enabled smart grid: A status update on technology framework and applications. IEEE Access 2019, 7, 97959-97973. [CrossRef]

125. Khan, M.W.; Wang, J.; Xiong, L.; Ma, M. Modelling and optimal management of distributed microgrid using multi-agent systems. Sustain. Cities Soc. 2018, 41, 154-169. [CrossRef]

126. Kong, X.; Liu, D.; Xiao, J.; Wang, C. A multi-agent optimal bidding strategy in microgrids based on artificial immune system. Energy 2019, 189, 116154. [CrossRef]

127. Espín-Sarzosa, D.; Palma-Behnke, R.; Núñez-Mata, O. Energy management systems for microgrids: Main existing trends in centralized control architectures. Energies 2020, 13, 547. [CrossRef]

128. Abdi, H.; Beigvand, S.D.; la Scala, M. A review of optimal power flow studies applied to smart grids and microgrids. Renew. Sustain. Energy Rev. 2017, 71, 742-766. [CrossRef]

129. Van Vuuren, D.P.; Stehfest, E.; Gernaat, D.E.; Doelman, J.C.; Van den Berg, M.; Harmsen, M.; de Boar, H.S.; Bouwman, L.F.; Daioglou, V.; Edelenbosch, O.Y.; et al. Energy, land-use and greenhouse gas emissions trajectories under a green growth paradigm. Glob. Environ. Chang. 2017, 42, 237-250. [CrossRef]

130. Ghadi, M.J.; Ghavidel, S.; Rajabi, A.; Azizivahed, A.; Li, L.; Zhang, J. A review on economic and technical operation of active distribution systems. Renew. Sustain. Energy Rev. 2019, 104, 38-53. [CrossRef]

131. Mariam, L.; Basu, M.; Conlon, M.F. Microgrid: Architecture, policy and future trends. Renew. Sustain. Energy Rev. 2016, 64, 477-489. [CrossRef]

132. Farrokhabadi, M.; Solanki, B.V.; Canizares, C.A.; Bhattacharya, K.; Koenig, S.; Sauter, P.S.; Leibfried, T.; Hohmann, S. Energy Storage in Microgrids: Compensating for Generation and Demand Fluctuations while Providing Ancillary Services. IEEE Power Energy Mag. 2017, 15, 81-91. [CrossRef]

133. Adefarati, T.; Bansal, R.C. Energizing Renewable Energy Systems and Distribution Generation. Pathw. A Smarter Power System. 2019, 29-65. [CrossRef]

134. Chong, W.T.; Muzammil, W.K.; Ong, H.C.; Sopian, K.; Gwani, M.; Fazlizan, A.; Poh, S.C. Performance analysis of the deflector integrated cross axis wind turbine. Renew. Energy 2019, 138, 675-690. [CrossRef]

135. Tabatabaeikia, S.; Ghazali, N.N.B.N.; Chong, W.T.; Shahizare, B.; Izadyar, N.; Esmaeilzadeh, A.; Fazlizan, A. Computational and experimental optimization of the exhaust air energy recovery wind turbine generator. Energy Convers. Manag. 2016, 126, 862-874. [CrossRef]

136. Balducci, P.J.; Alam, M.J.E.; Hardy, T.D.; Wu, D. Assigning value to energy storage systems at multiple points in an electrical grid. Energy Environ. Sci. 2018, 11, 1926-1944. [CrossRef]

137. Katsanevakis, M.; Stewart, R.A.; Lu, J. Aggregated applications and benefits of energy storage systems with application-specific control methods: A review. Renew. Sustain. Energy Rev. 2017, 75, 719-741. [CrossRef] 
138. Rosman, M.R.M. The Role of Business Processes in Influencing the Decision Support Capabilities of Enterprise Content Management System (ECMS): Towards a Framework. Asia-Pac. J. Inf. Technol. Multimed. 2020, 9, 58-68. [CrossRef]

139. Hartmann, B.; Táczi, I.; Talamon, A.; Vokony, I. Island mode operation in intelligent microgrid-Extensive analysis of a case study. Int. Trans. Electr. Energy Systems. 2021, 31, 12950. [CrossRef]

140. Nosratabadi, S.M.; Hooshmand, R.A.; Gholipour, E. A comprehensive review on microgrid and virtual power plant concepts employed for distributed energy resources scheduling in power systems. Renew. Sustain. Energy Rev. 2017, 67, 341-363. [CrossRef]

141. Isa, N.M.; Tan, C.W.; Yatim, A.H.M. A comprehensive review of cogeneration system in a microgrid: A perspective from architecture and operating system. Renew. Sustain. Energy Rev. 2018, 81, 2236-2263. [CrossRef]

142. Hirsch, A.; Parag, Y.; Guerrero, J. Microgrids: A review of technologies, key drivers, and outstanding issues. Renew. Sustain. Energy Rev. 2018, 90, 402-411. [CrossRef]

143. Kalt, G.; Wiedenhofer, D.; Görg, C.; Haberl, H. Conceptualizing energy services: A review of energy and well-being along the Energy Service Cascade. Energy Res. Soc. Sci. 2019, 53, 47-58. [CrossRef]

144. Su, Y.W. Residential electricity demand in Taiwan: Consumption behavior and rebound effect. Energy Policy 2019, 124, 36-45. [CrossRef]

145. Li, C.; Song, Y.; Kaza, N. Urban form and household electricity consumption: A multilevel study. Energy Build. 2018, 158, 181-193. [CrossRef]

146. Srivastava, C.; Yang, Z.; Jain, R.K. Understanding the adoption and usage of data analytics and simulation among building energy management professionals: A nationwide survey. Build. Environ. 2019, 157, 139-164. [CrossRef]

147. Ruzbahani, H.M.; Karimipour, H. Optimal incentive-based demand response management of smart households. In Proceedings of the 2018 IEEE/IAS 54th Industrial and Commercial Power Systems Technical Conference (I\&CPS), Niagara Falls, ON, Canada, 7-10 May 2018; pp. 1-7. [CrossRef]

148. Prabatha, T.; Hager, J.; Carneiro, B.; Hewage, K.; Sadiq, R. Analyzing energy options for small-scale off-grid communities: A Canadian case study. J. Clean. Prod. 2020, 249, 119320. [CrossRef]

149. Sinsel, S.R.; Riemke, R.L.; Hoffmann, V.H. Challenges and solution technologies for the integration of variable renewable energy sources-A review. Renew. Energy 2020, 145, 2271-2285. [CrossRef]

150. Alamo, D.H.; Medina, R.N.; Ruano, S.D.; García, S.S.; Moustris, K.P.; Kavadias, K.K.; Zafiraks, D.; Tzanes, G.; Zafeiraki, E.; Spyropoulos, G.; et al. An Advanced Forecasting System for the Optimum Energy Management of Island Microgrids. Energy Procedia 2019, 159, 111-116. [CrossRef]

151. Cojocaru, E.G.; Bravo, J.M.; Vasallo, M.J.; Santos, D.M. Optimal scheduling in concentrating solar power plants oriented to low generation cycling. Renew. Energy 2019, 135, 789-799. [CrossRef]

152. Morais, H.; Kádár, P.; Cardoso, M.; Vale, Z.A.; Khodr, H. VPP Operating in the Isolated Grid. In Proceedings of the IEEE Power and Energy Society 2008 General Meeting: Conversion and Delivery of Electrical Energy in the 21st Century, PES, Pittsburgh, PA, USA, 20-24 July 2008. [CrossRef]

153. Bai, H.; Miao, S.; Ran, X.; Ye, C. Optimal dispatch strategy of a virtual power plant containing battery switch stations in a unified electricity market. Energies 2015, 8, 2268-2289. [CrossRef]

154. Zhou, K.; Yang, S.; Shao, Z. Energy Internet: The business perspective. Appl. Energy 2016, 178, 212-222. [CrossRef]

155. Zamani, A.G.; Zakariazadeh, A.; Jadid, S.; Kazemi, A. Stochastic operational scheduling of distributed energy resources in a large scale virtual power plant. Int. J. Electr. Power Energy Syst. 2016, 82, 608-620. [CrossRef]

156. Peik-Herfeh, M.; Seifi, H.; Sheikh-El-Eslami, M.K. Two-stage approach for optimal dispatch of distributed energy resources in distribution networks considering virtual power plant concept. Int. Trans. Electr. Energy Syst. 2014, 24, 43-63. [CrossRef]

157. Petrovic, N.; Strezoski, L.; Dumnic, B. Overview of software tools for integration and active management of high penetration of DERs in emerging distribution networks. In Proceedings of the EUROCON 2019-18th International Conference on Smart Technologies, Novi Sad, Serbia, 1-4 July 2019. [CrossRef]

158. Lombardi, P.; Powalko, M.; Rudion, K. Optimal Operation of a Virtual Power Plant. In Proceedings of the 2009 IEEE Power and Energy Society General Meeting, PES '09, Calgary, AB, Canada, 26-30 July 2009. [CrossRef]

159. Justo, J.J. Intelligent energy management strategy considering power distribution networks with nanogrids, microgrids, and VPP concepts. Handb. Distrib. Gener. Electr. Power Technol. Econ. Environ. Impacts. 2017, 791-815. [CrossRef]

160. Adeyemi, A.; Yan, M.; Shahidehpour, M.; Bahramirad, S.; Paaso, A. Transactive energy markets for managing energy exchanges in power distribution systems. Electr. J. 2020, 33, 106868. [CrossRef]

161. Adu-Kankam, K.O.; Camarinha-Matos, L.M. Towards collaborative Virtual Power Plants: Trends and convergence. Sustain. Energy Grids Netw. 2018, 16, 217-230. [CrossRef]

162. Gharaibeh, A.; Salahuddin, M.A.; Hussini, S.J.; Khreishah, A.; Khalil, I.; Guizani, M.; Al-Fuqaha, A. Smart Cities: A Survey on Data Management, Security, and Enabling Technologies. IEEE Commun. Surv. Tutor. 2017, 19, 2456-2501. [CrossRef]

163. Hameed, A.; Khoshkbarforoushha, A.; Ranjan, R.; Jayaraman, P.P.; Kolodziej, J.; Balaji, P.; Zeadally, S.; Malluhi, Q.M.; Tziritas, N.; Vishnu, A.; et al. A survey and taxonomy on energy efficient resource allocation techniques for cloud computing systems. Computing 2016, 98, 751-774. [CrossRef]

164. Diaby, T.; Rad, B.B. Cloud Computing: A review of the Concepts and Deployment Models. Int. J. Inf. Technol. Comput. Sci. 2017, 9 , 50-58. [CrossRef] 
165. Faheem, M.; Akram, U.; Khan, I.; Naqeeb, S.; Shahzad, A.; Ullah, A. Cloud computing environment and security challenges: A review. Int. J. Adv. Comput. Sci. Appl. 2017, 8, 183-195. [CrossRef]

166. Rashid, A.; Chaturvedi, A. Cloud Computing Characteristics and Services: A Brief Review. Int. J. Comput. Sci. Eng. 2019, 7, 421-426. [CrossRef]

167. Nieuwenhuis, L.J.M.; Ehrenhard, M.L.; Prause, L. The shift to Cloud Computing: The impact of disruptive technology on the enterprise software business ecosystem. Technol. Forecast. Soc. Chang. 2018, 129, 308-313. [CrossRef]

168. Ghahramani, M.H.; Zhou, M.; Hon, C.T. Toward cloud computing QoS architecture: Analysis of cloud systems and cloud services. IEEE/CAA J. Autom. Sin. 2017, 4, 6-18. [CrossRef]

169. Shehabi, A.; Smith, S.J.; Masanet, E.; Koomey, J. Data center growth in the United States: Decoupling the demand for services from electricity use. Environ. Res. Lett. 2018, 13, 124030. [CrossRef]

170. Cahyani, N.D.W.; Martini, B.; Choo, K.K.R.; Al-Azhar, A.M.N. Forensic data acquisition from cloud-of-things devices: Windows Smartphones as a case study. Concurr. Comput. 2017, 29, e3855. [CrossRef]

171. Tassone, C.F.R.; Martini, B.; Choo, K.K.R. Visualizing Digital Forensic Datasets: A Proof of Concept. J. Forensic Sci. 2017, 62, 1197-1204. [CrossRef] [PubMed]

172. Rani, R.; Kumar, N.; Khurana, M.; Kumar, A.; Barnawi, A. Storage as a service in Fog computing: A systematic review. J. Syst. Archit. 2021, 116, 102033. [CrossRef]

173. Aazam, M.; Huh, E.N. Fog computing micro datacenter based dynamic resource estimation and pricing model for IoT. In Proceedings of the 2015 IEEE 29th International Conference on Advanced Information Networking and Applications, Gwangju, Korea, 24-27 March 2015; pp. 687-694. [CrossRef]

174. Libertson, F.; Velkova, J.; Palm, J. Data-center infrastructure and energy gentrification: Perspectives from Sweden. Sustain. Sci. Pract. Policy 2021, 17, 153-162. [CrossRef]

175. Kumar, M.; Sharma, S.C. Deadline constrained based dynamic load balancing algorithm with elasticity in cloud environment. Comput. Electr. Eng. 2018, 69, 395-411. [CrossRef]

176. Kumar, M.; Dubey, K.; Sharma, S.C. Elastic and flexible deadline constraint load Balancing algorithm for Cloud Computing. Procedia Comput. Sci. 2018, 125, 717-724. [CrossRef]

177. Rana, S.G.H. Cloud Resource Optimization: Comparison of Probabilistic Optimization Algorithms. 2017. Available online: https:/ / www.flackbox.com/cloud-resource-pooling-tutorial (accessed on 16 August 2021).

178. Abohamama, A.S.; Hamouda, E. A hybrid energy-Aware virtual machine placement algorithm for cloud environments. Expert Syst. Appl. 2020, 150. [CrossRef]

179. Wang, Q.; Cai, H.; Cao, Q.; Wang, F. An energy-efficient power management for heterogeneous servers in data centers. Computing 2020, 102, 1717-1741. [CrossRef]

180. Zhang, S.; Qian, Z.; Luo, Z.; Wu, J.; Lu, S. Burstiness-Aware Resource Reservation for Server Consolidation in Computing Clouds. IEEE Trans. Parallel Distrib. Syst. 2016, 27, 964-977. [CrossRef]

181. Selim, G.E.I.; El-Rashidy, M.A.; El-Fishawy, N.A. An efficient resource utilization technique for consolidation of virtual machines in cloud computing environments. In Proceedings of the National Radio Science Conference, NRSC, Aswan, Egypt, 22-25 February 2016; pp. 316-324. [CrossRef]

182. Orgerie, A.C.; de Assuncao, M.D.; Lefevre, L. A survey on techniques for improving the energy efficiency of large-scale distributed systems. ACM Comput. Surv. 2014, 46, 1-31. [CrossRef]

183. Haghighi, M.A.; Maeen, M.; Haghparast, M. An Energy-Efficient Dynamic Resource Management Approach Based on Clustering and Meta-Heuristic Algorithms in Cloud Computing IaaS Platforms: Energy Efficient Dynamic Cloud Resource Management. Wirel. Pers. Commun. 2019, 104, 1367-1391. [CrossRef]

184. Forestiero, A.; Mastroianni, C.; Meo, M.; Papuzzo, G.; Sheikhalishahi, M. Hierarchical Approach for Efficient Workload Management in Geo-Distributed Data Centers. IEEE Trans. Green Commun. Netw. 2017, 1, 97-111. [CrossRef]

185. Tribus, M.; McIrvine, E.C. Energy and Information. Sci. Am. 1971, 225, 179-188. [CrossRef]

186. Gupta, B.B.; Quamara, M. An overview of Internet of Things (IoT): Architectural aspects, challenges, and protocols. Concurr. Comput. 2020, 32, e4946. [CrossRef]

187. Hanini, M.; el Kafhali, S.; Salah, K. Dynamic VM allocation and traffic control to manage QoS and energy consumption in cloud computing environment. Int. J. Comput. Appl. Technol. 2019, 60, 307-316. [CrossRef]

188. Rashid, Z.N.; Zebari, S.R.M.; Sharif, K.H.; Jacksi, K. Distributed Cloud Computing and Distributed Parallel Computing: A Review. In Proceedings of the ICOASE 2018-International Conference on Advanced Science and Engineering, Duhok, Iraq, 9-11 October 2018; pp. 167-172. [CrossRef]

189. Dabbagh, M.; Hamdaoui, B.; Rayes, A. Peak Power Shaving for Reduced Electricity Costs in Cloud Data Centers: Opportunities and Challenges. IEEE Netw. 2020, 34, 148-153. [CrossRef]

190. Simmhan, Y.; Giakkoupis, M. On using cloud platforms in a software architecture for smart energy grids. In Proceedings of the IEEE International Conference on Cloud Computing (CloudCom), Indianapolis, IN, USA, 30 November-3 December 2010; pp. 1-3. Available online: http:/ / citeseerx.ist.psu.edu/viewdoc/download?doi=10.1.1.232.2334\&rep=rep1\&type=pdf (accessed on 16 August 2021). 
191. Hasan, M.K.; Ahmed, M.M.; Musa, S.S.; Islam, S.; Abdullah, S.N.H.S.; Hossain, E.; Nafi, N.S.; Vo, N. An Improved Dynamic Thermal Current Rating Model for PMU-Based Wide Area Measurement Framework for Reliability Analysis Utilizing Sensor Cloud System. IEEE Access 2021, 9, 14446-14458. [CrossRef]

192. Elomari, A.; Hassouni, L.; Maizate, A. The main characteristics of five distributed file systems required for big data: A comparative study. Adv. Sci. Technol. Eng. Syst. 2017, 2, 78-91. [CrossRef]

193. Ahmad, A.; Khan, M.; Paul, A.; Din, S.; Rathore, M.M.; Jeon, G.; Choi, G.S. Toward modeling and optimization of features selection in Big Data based social Internet of Things. Future Gener. Comput. Syst. 2018, 82, 715-726. [CrossRef]

194. Zhong, R.Y.; Newman, S.T.; Huang, G.Q.; Lan, S. Big Data for supply chain management in the service and manufacturing sectors: Challenges, opportunities, and future perspectives. Comput. Ind. Eng. 2016, 101, 572-591. [CrossRef]

195. Mustafa, H.M.J.; Ayob, M.; Albashish, D.; Abu-Taleb, S. Solving text clustering problem using a memetic differential evolution algorithm. PLoS ONE 2020, 15, e0232816. [CrossRef]

196. Bilal, M.; Oyedele, L.O.; Qadir, J.; Munir, K.; Ajayi, S.O.; Akinade, O.O.; Owolabi, H.A.; Alaka, H.A.; Pasha, M. Big Data in the construction industry: A review of present status, opportunities, and future trends. Adv. Eng. Inform. 2016, 30, 500-521. [CrossRef]

197. Li, Y.; Yu, M.; Xu, M.; Yang, J.; Sha, D.; Liu, Q.; Yang, C. Big data and cloud computing. In Manual of Digital Earth; Springer: Singapore, 2020; pp. 325-355. [CrossRef]

198. Costin, A.; Adibfar, A.; Hu, H.; Chen, S.S. Building Information Modeling (BIM) for transportation infrastructure-Literature review, applications, challenges, and recommendations. Autom. Constr. 2018, 94, 257-281. [CrossRef]

199. Chen, C.L.P.; Zhang, C.Y. Data-intensive applications, challenges, techniques and technologies: A survey on Big Data. Inf. Sci. 2014, 275, 314-347. [CrossRef]

200. Kambatla, K.; Kollias, G.; Kumar, V.; Grama, A. Trends in big data analytics. J. Parallel Distrib. Comput. 2014, 74, $2561-2573$. [CrossRef]

201. Hu, H.; Wen, Y.; Chua, T.S.; Li, X. Toward scalable systems for big data analytics: A technology tutorial. IEEE Access 2014, 2, 652-687. [CrossRef]

202. Tu, C.; He, X.; Shuai, Z.; Jiang, F. Big data issues in smart grid-A review. Renew. Sustain. Energy Rev. 2017, 79, 1099-1107. [CrossRef]

203. Saleem, Y.; Crespi, N.; Rehmani, M.H.; Copeland, R. Internet of Things-Aided Smart Grid: Technologies, Architectures, Applications, Prototypes, and Future Research Directions. IEEE Access 2019, 7, 62962-63003. [CrossRef]

204. Marjani, M.; Nasaruddin, F.; Gani, A.; Karim, A.; Hashem, I.A.T.; Siddiqa, A.; Yaqoob, I. Big IoT Data Analytics: Architecture, Opportunities, and Open Research Challenges. IEEE Access 2017, 5, 5247-5261. [CrossRef]

205. Zhu, T.; Xiao, S.; Zhang, Q.; Gu, Y.; Yi, P.; Li, Y. Emergent Technologies in Big Data Sensing: A Survey. Int. J. Distrib. Sens. Netw. 2015, 11, 902982. [CrossRef]

206. Jiang, H.; Wang, K.; Wang, Y.; Gao, M.; Zhang, Y. Energy big data: A survey. IEEE Access 2016, 4, 3844-3861. [CrossRef]

207. Ahmed, S.; Gondal, T.M.; Adil, M.; Malik, S.A.; Qureshi, R. A Survey on Communication Technologies in Smart Grid. In Proceedings of the 2019 IEEE PES GTD Grand International Conference and Exposition Asia, GTD Asia 2019, Bangkok, Thailand, 19-23 March 2019; pp. 7-12. [CrossRef]

208. Yang, T. ICT technologies standards and protocols for active distribution network. Smart Power Distrib. Syst. Control. Commun. Optim. 2018, 205-230. [CrossRef]

209. Baesens, B.; Bapna, R.; Marsden, J.R.; Vanthienen, J.; Zhao, J.L. Transformational issues of big data and analytics in networked business. MIS Q. Manag. Inf. Syst. 2016, 40, 807-818. [CrossRef]

210. Sagiroglu, S.; Terzi, R.; Canbay, Y.; Colak, I. Big data issues in smart grid systems. In Proceedings of the 2016 IEEE International Conference on Renewable Energy Research and Applications, ICRERA 2016, Birmingham, UK, 20-23 November 2016; pp. 1007-1012. [CrossRef]

211. El-Mawla, N.A.; Badawy, M.; Arafat, H. IoT for the Failure of Climate-Change Mitigation and Adaptation and IIoT as a Future Solution. World J. Environ. Eng. 2019, 6, 7-16. [CrossRef]

212. Daki, H.; el Hannani, A.; Aqqal, A.; Haidine, A.; Dahbi, A. Big Data management in smart grid: Concepts, requirements and implementation. J. Big Data 2017, 4, 13. [CrossRef]

213. Zhang, Y.; Huang, T.; Bompard, E.F. Big data analytics in smart grids: A review. Energy Inform. 2016, 1, 8. [CrossRef]

214. Ponocko, J.; Milanovic, J.V. Forecasting Demand Flexibility of Aggregated Residential Load Using Smart Meter Data. IEEE Trans. Power Syst. 2018, 33, 5446-5455. [CrossRef]

215. Kalalas, C.; Thrybom, L.; Alonso-Zarate, J. Cellular communications for smart grid neighborhood area networks: A survey. IEEE Access 2016, 4, 1469-1493. [CrossRef]

216. Yu, R.; Zhang, Y.; Chen, Y. Hybrid spectrum access in cognitive Neighborhood Area Networks in the smart grid. In Proceedings of the IEEE Wireless Communications and Networking Conference, WCNC, Paris, France, 1-4 April 2012; pp. 1478-1483. [CrossRef]

217. Güngör, V.C.; Sahin, D.; Kocak, T.; Ergüt, S.; Buccella, C.; Cecati, C.; Hancke, G.P. Smart Grid Technologies: Communication Technologies and Standards. IEEE Trans. Ind. Inf. 2011, 7, 529-539. [CrossRef]

218. Baimel, D.; Tapuchi, S.; Baimel, N. Smart grid communication technologies-Overview, research challenges and opportunities. In Proceedings of the 2016 International Symposium on Power Electronics, Electrical Drives, Automation and Motion, SPEEDAM, Capri, Italy, 22-24 June 2016; pp. 116-120. [CrossRef] 
219. Gibert, K.; Sànchez-Marrè, M.; Izquierdo, J. A survey on pre-processing techniques: Relevant issues in the context of environmental data mining. AI Commun. 2016, 29, 627-663. [CrossRef]

220. Fernández, A.; del Río, S.; Chawla, N.V.; Herrera, F. An insight into imbalanced Big Data classification: Outcomes and challenges. Complex Intell. Syst. 2017, 3, 105-120. [CrossRef]

221. Juneja, A.; Das, N.N. Big Data Quality Framework: Pre-Processing Data in Weather Monitoring Application. In Proceedings of the International Conference on Machine Learning, Big Data, Cloud and Parallel Computing: Trends, Prespectives and Prospects, COMITCon2019, Faridabad, India, 14-16 February 2019; pp. 559-563. [CrossRef]

222. Shi, W.; Zhu, Y.; Huang, T.; Sheng, G.; Lian, Y.; Wang, G.; Chen, Y. An Integrated Data Preprocessing Framework Based on Apache Spark for Fault Diagnosis of Power Grid Equipment. J. Signal Process. Syst. 2017, 86, 221-236. [CrossRef]

223. Dileep, G. A survey on smart grid technologies and applications. Renew. Energy 2020, 146, 2589-2625. [CrossRef]

224. Kar, S.; Samantaray, S.R.; Zadeh, M.D. Data-Mining Model Based Intelligent Differential Microgrid Protection Scheme. IEEE Syst. J. 2017, 11, 1161-1169. [CrossRef]

225. Silva, B.N.; Khan, M.; Jung, C.; Seo, J.; Muhammad, D.; Han, J.; Yoon, Y.; Han, K. Urban planning and smart city decision management empowered by real-time data processing using big data analytics. Sensors 2018, 18, 2994. [CrossRef]

226. Sharma, E. Energy forecasting based on predictive data mining techniques in smart energy grids. Energy Inform. 2018, 1, 367-373. [CrossRef]

227. Siryani, J.; Tanju, B.; Eveleigh, T.J. A Machine Learning Decision-Support System Improves the Internet of Things' Smart Meter Operations. IEEE Internet Things J. 2017, 4, 1056-1066. [CrossRef]

228. Albashish, D.; Hammouri, A.I.; Braik, M.; Atwan, J.; Sahran, S. Binary biogeography-based optimization based SVM-RFE for feature selection. Appl. Soft Comput. 2021, 101, 107026. [CrossRef]

229. Samantaray, S.R.; Mishra, D.P.; Joos, G.; Samantaray, S.R.; Joos, G. A Combined Wavelet and Data-Mining Based Intelligent Protection Scheme for Microgrid. IEEE Trans. Smart Grid 2018, 7, 2295-2304. [CrossRef]

230. Hashemi, F.; Mohammadi, M.; Kargarian, A. Islanding detection method for microgrid based on extracted features from differential transient rate of change of frequency. IET Gener. Transm. Distrib. 2017, 11, 891-904. [CrossRef]

231. Alam, M.R.; Muttaqi, K.M.; Bouzerdoum, A. Evaluating the effectiveness of a machine learning approach based on response time and reliability for islanding detection of distributed generation. IET Renew. Power Gener. 2017, 11, 1392-1400. [CrossRef]

232. Elkadeem, M.R.; Alaam, M.A.; Azmy, A.M. Improving performance of underground MV distribution networks using distribution automation system: A case study. Ain Shams Eng. J. 2018, 9, 469-481. [CrossRef]

233. Santis, E.D.; Rizzi, A.; Sadeghian, A. A learning intelligent System for classification and characterization of localized faults in Smart Grids. In Proceedings of the 2017 IEEE Congress on Evolutionary Computation, CEC 2017-Proceedings, Donostia-San Sebastián, Spain, 5-8 June 2017; pp. 2669-2676. [CrossRef]

234. Wang, J.; Xiong, X.; Zhou, N.; Li, Z.; Wang, W. Early warning method for transmission line galloping based on SVM and AdaBoost bi-level classifiers. IET Gener. Transm. Distrib. 2016, 10, 3499-3507. [CrossRef]

235. Zhang, Y.; Xu, Y.; Dong, Z.Y.; Xu, Z.; Wong, K.P. Intelligent early warning of power system dynamic insecurity Risk: Toward optimal accuracy-earliness tradeoff. IEEE Trans. Ind. Inform. 2017, 13, 2544-2554. [CrossRef]

236. Cui, Q.; El-Arroudi, K.; Joos, G. An effective feature extraction method in pattern recognition based high impedance fault detection. In Proceedings of the 2017 19th International Conference on Intelligent System Application to Power Systems (ISAP), San Antonio, TX, USA, 17-20 September 2017. [CrossRef]

237. Zhu, L.; Lu, C.; Dong, Z.Y.; Hong, C. Imbalance Learning Machine-Based Power System Short-Term Voltage Stability Assessment. IEEE Trans. Ind. Inform. 2017, 13, 2533-2543. [CrossRef]

238. Flynn, D.; Rather, Z.; Ardal, A.; D’Arco, S.; Hansen, A.D.; Cutululis, N.A.; Sorensen, P.; Estanquiero, A.; Gómez, E.; Menemenlis, N.; et al. Technical impacts of high penetration levels of wind power on power system stability. Wiley Interdiscip. Rev. Energy Environ. 2017, 6, e216. [CrossRef]

239. Liu, C.; Sun, K.; Rather, Z.H.; Chen, Z.; Bak, C.L.; Thøgersen, P.; Lund, P. A systematic approach for dynamic security assessment and the corresponding preventive control scheme based on decision trees. IEEE Trans. Power Syst. 2014, 29, 717-730. [CrossRef]

240. He, C.; Guan, L.; Mo, W. A method for transient stability assessment based on pattern recognition. In Proceedings of the 2016 International Conference on Smart Grid and Clean Energy Technologies, ICSGCE 2016, Chengdu, China, 19-22 October 2016; pp. 343-347. [CrossRef]

241. Dimitrovska, T.; Rudez, U.; Mihalic, R. Fast contingency screening based on data mining. In Proceedings of the 17th IEEE International Conference on Smart Technologies, EUROCON 2017-Conference Proceedings, Ohrid, Macedonia, 6-8 July 2017; pp. 794-798. [CrossRef]

242. Andalib-Bin-Karim, C.; Liang, X.; Khan, N.; Zhang, H. Determine Q-V Characteristics of Grid-Connected Wind Farms for Voltage Control Using a Data-Driven Analytics Approach. IEEE Trans. Ind. Appl. 2017, 53, 4162-4175. [CrossRef]

243. Kalair, A.; Abas, N.; Saleem, M.S.; Kalair, A.R.; Khan, N. Role of energy storage systems in energy transition from fossil fuels to renewables. Energy Storage 2021, 3, e135. [CrossRef]

244. Swetapadma, A.; Yadav, A. Data-mining-based fault during power swing identification in power transmission system. IET Sci. Meas. Technol. 2016, 10, 130-139. [CrossRef]

245. Jena, M.K.; Samantaray, S.R. Data-Mining-Based Intelligent Differential Relaying for Transmission Lines Including UPFC and Wind Farms. IEEE Trans. Neural Netw. Learn. Syst. 2016, 27, 8-17. [CrossRef] [PubMed] 
246. Papadopoulos, P.N.; Guo, T.; Milanović, J.V. Probabilistic framework for online identification of dynamic behavior of power systems with renewable generation. IEEE Trans. Power Syst. 2018, 33, 45-54. [CrossRef]

247. Deng, X.; Bian, D.; Wang, W.; Jiang, Z.; Yao, W.; Qiu, W.; Tong, N.; Shi, D.; Liu, Y. Deep learning model to detect various synchrophasor data anomalies. IET Gener. Transm. Distrib. 2020, 14, 5816-5822. [CrossRef]

248. Tan, B.; Yang, J.; Tang, Y.; Jiang, S.; Xie, P.; Yuan, W. A Deep Imbalanced Learning Framework for Transient Stability Assessment of Power System. IEEE Access 2019, 7, 81759-81769. [CrossRef]

249. Wei, L.; Dongxia, Z.; Xinying, W.; Daowei, L.; Qian, W. Power system transient stability analysis based on random matrix theory. Proc. CSEE 2016, 36, 4854-4863.

250. Xu, X.Y.; He, X.; Ai, Q.; Qiu, C.M. A correlation analysis method for operation status of distribution network based on random matrix theory. Power Syst. Technol. 2016, 40, 781-790.

251. Malbasa, V.; Zheng, C.; Chen, P.C.; Popovic, T.; Kezunovic, M. Voltage Stability Prediction Using Active Machine Learning. IEEE Trans. Smart Grid 2017, 8, 3117-3124. [CrossRef]

252. Zhang, J.; Chung, C.Y.; Wang, Z.; Zheng, X. Instantaneous Electromechanical Dynamics Monitoring in Smart Transmission Grid. IEEE Trans. Ind. Inform. 2016, 12, 844-852. [CrossRef]

253. Zhao, J.; Zhang, G.; Das, K.; Korres, G.N.; Manousakis, N.M.; Sinha, A.K.; He, Z. Power system real-time monitoring by using PMU-based robust state estimation method. IEEE Trans. Smart Grid 2016, 7, 300-309. [CrossRef]

254. Shah, Z.; Anwar, A.; Mahmood, A.N.; Tari, Z.; Zomaya, A.Y. A Spatiotemporal Data Summarization Approach for Real-Time Operation of Smart Grid. IEEE Trans. Big Data 2020, 6, 624-637. [CrossRef]

255. Lv, Z.; Song, H.; Basanta-Val, P.; Steed, A.; Jo, M. Next-Generation Big Data Analytics: State of the Art, Challenges, and Future Research Topics. IEEE Trans. Ind. Inform. 2017, 13, 1891-1899. [CrossRef]

256. Reinhardt, A.; Reinhardt, D. Detecting anomalous electrical appliance behavior based on motif transition likelihood matrices. In Proceedings of the 2016 IEEE International Conference on Smart Grid Communications, SmartGridComm 2016, Sydney, NSW, Australia, 6-9 November 2016; pp. 680-685. [CrossRef]

257. Sheng, G.; Hou, H.; Jiang, X.; Chen, Y. A novel association rule mining method of big data for power transformers state parameters based on probabilistic graph model. IEEE Trans. Smart Grid 2018, 9, 695-702. [CrossRef]

258. Png, E.; Srinivasan, S.; Bekiroglu, K.; Chaoyang, J.; Su, R.; Poolla, K. An internet of things upgrade for smart and scalable heating, ventilation and air-conditioning control in commercial buildings. Appl. Energy 2019, 239, 408-424. [CrossRef]

259. Allen, W.H.; Rubaai, A.; Chawla, R. Fuzzy Neural Network-Based Health Monitoring for HVAC System Variable-Air-Volume Unit. IEEE Trans. Ind. Appl. 2016, 52, 2513-2524. [CrossRef]

260. Azmi, A.; Jasni, J.; Azis, N.; Kadir, M.Z.A.A. Evolution of transformer health index in the form of mathematical equation. Renew. Sustain. Energy Rev. 2017, 76, 687-700. [CrossRef]

261. Goyal, R.; Whelan, M.J.; Cavalline, T.L. Characterising the effect of external factors on deterioration rates of bridge components using multivariate proportional hazards regression. Struct. Infrastruct. Eng. 2017, 13, 894-905. [CrossRef]

262. Moradi, R.; Groth, K.M. Modernizing risk assessment: A systematic integration of PRA and PHM techniques. Reliab. Eng. Syst. Saf. 2020, 204, 107194. [CrossRef]

263. Balouji, E.; Salor, O. Classification of power quality events using deep learning on event images. In Proceedings of the 3rd International Conference on Pattern Analysis and Image Analysis, IPRIA 2017, Shahrekord, Iran, 19-20 April 2017 ; pp. 216-221. [CrossRef]

264. Borges, F.A.S.; Fernandes, R.A.S.; Silva, I.N.; Silva, C.B.S. Feature Extraction and Power Quality Disturbances Classification Using Smart Meters Signals. IEEE Trans. Ind. Inform. 2016, 12, 824-833. [CrossRef]

265. Potter, C.W.; Archambault, A.; Westrick, K. Building a smarter smart grid through better renewable energy information. In Proceedings of the 2009 IEEE/PES Power Systems Conference and Exposition, PSCE 2009, Seattle, WA, USA, 15-18 March 2009. [CrossRef]

266. Alonso, M.; Amaris, H.; Alcala, D.; Florez, D.M.R. Smart sensors for smart grid reliability. Sensors 2020, 20, 2187. [CrossRef] [PubMed]

267. Jimada-Ojuolapea, B.; Teh, J. Surveys on the reliability impacts of power system cyber-physical layers. Sustain. Cities Soc. 2020, 62, 102384. [CrossRef]

268. Brijesh, P.; Lal, A.G.; Manju, A.S.; Joseph, A. Synchrophasors evaluation and applications. In Proceedings of the 2018 IEEE Texas Power and Energy Conference, TPEC 2018, College Station, TX, USA, 8-9 February 2018; Volume 2018, pp. 1-6. [CrossRef]

269. Olvera, J.P.; Green, T.; Junyent-Ferre, A. Using Multi-Terminal DC Networks to Improve the Hosting Capacity of Distribution Networks. In Proceedings of the Proceedings-2018 IEEE PES Innovative Smart Grid Technologies Conference Europe, ISGTEurope 2018, Sarajevo, Bosnia and Herzegovina, 21-25 October 2018. [CrossRef]

270. Elbreki, A.M.; Sopian, K.; Fazlizan, A.; Ibrahim, A. An innovative technique of passive cooling PV module using lapping fins and planner reflector. Case Stud. Therm. Eng. 2020, 19, 100607. [CrossRef]

271. Kumar, H.; Singh, M.K.; Gupta, M.P.; Madaan, J. Moving towards smart cities: Solutions that lead to the Smart City Transformation Framework. Technol. Forecast. Soc. Chang. 2020, 153, 119281. [CrossRef]

272. Haben, S.; Arora, S.; Giasemidis, G.; Voss, M.; Greetham, D.V. Review of Low-Voltage Load Forecasting: Methods, Applications, and Recommendations. 2021. Available online: http:/ / arxiv.org/abs/2106.00006 (accessed on 7 October 2021). 
273. Hossain, M.S.; Madlool, N.A.; Rahim, N.A.; Selvaraj, J.; Pandey, A.K.; Khan, A.F. Role of smart grid in renewable energy: An overview. Renew. Sustain. Energy Rev. 2016, 60, 1168-1184. [CrossRef]

274. Wu, W.; Peng, M. A Data Mining Approach Combining K-Means Clustering with Bagging Neural Network for Short-Term Wind Power Forecasting. IEEE Internet Things J. 2017, 4, 979-986. [CrossRef]

275. Yang, M.; Lin, Y.; Han, X. Probabilistic Wind Generation Forecast Based on Sparse Bayesian Classification and Dempster-Shafer Theory. IEEE Trans. Ind. Appl. 2016, 52, 1998-2005. [CrossRef]

276. Khodayar, M.; Kaynak, O.; Khodayar, M.E. Rough Deep Neural Architecture for Short-Term Wind Speed Forecasting. IEEE Trans. Ind. Inform. 2017, 13, 2770-2779. [CrossRef]

277. Zhao, T.; Zhou, Z.; Zhang, Y.; Ling, P.; Tian, Y. Spatio-Temporal Analysis and Forecasting of Distributed PV Systems Diffusion: A Case Study of Shanghai Using a Data-Driven Approach. IEEE Access 2017, 5, 5135-5148. [CrossRef]

278. Nazaripouya, H.; Wang, B.; Wang, Y.; Chu, P.; Pota, H.R.; Gadh, R. Univariate time series prediction of solar power using a hybrid wavelet-ARMA-NARX prediction method. In Proceedings of the IEEE Power Engineering Society Transmission and Distribution Conference, Dallas, TX, USA, 3-5 May 2016. [CrossRef]

279. Tayab, U.B.; Zia, A.; Yang, F.; Lu, J.; Kashif, M. Short-term load forecasting for microgrid energy management system using hybrid HHO-FNN model with best-basis stationary wavelet packet transform. Energy 2020, 203, 117857. [CrossRef]

280. Ding, N.; Benoit, C.; Foggia, G.; Besanger, Y.; Wurtz, F. Neural network-based model design for short-term load forecast in distribution systems. IEEE Trans. Power Syst. 2016, 31, 72-81. [CrossRef]

281. Liu, D.; Zeng, L.; Li, C.; Ma, K.; Chen, Y.; Cao, Y. A Distributed Short-Term Load Forecasting Method Based on Local Weather Information. IEEE Syst. J. 2018, 12, 208-215. [CrossRef]

282. Shi, H.; Xu, M.; Li, R. Deep Learning for Household Load Forecasting-A Novel Pooling Deep RNN. IEEE Trans. Smart Grid 2018, 9, 5271-5280. [CrossRef]

283. Kong, W.; Dong, Z.Y.; Jia, Y.; Hill, D.J.; Xu, Y.; Zhang, Y. Short-Term Residential Load Forecasting based on LSTM Recurrent Neural Network. IEEE Trans. Smart Grid 2017, 10, 841-851. [CrossRef]

284. Meyn, S.; Samad, T.; Hiskens, I.; Stoustrup, J. Energy Markets and Responsive Grids. Modeling, Control, and Optimization. The IMA Volumes Mathematics Its Applications; 2018; 518p. Available online: https:/ /ink-springer-com.proxy.libraries.uc.edu/content/pdf/ 10.1007\%2F978-1-4939-7822-9.pdf (accessed on 16 August 2021).

285. Moreno-Munoz, A.; Bellido-Outeirino, F.J.; Siano, P.; Gomez-Nieto, M.A. Mobile social media for smart grids customer engagement: Emerging trends and challenges. Renew. Sustain. Energy Rev. 2016, 53, 1611-1616A. [CrossRef]

286. Cai, Y.; Huang, T.; Bompard, E.; Cao, Y.; Li, Y. Self-sustainable community of electricity prosumers in the emerging distribution system. IEEE Trans. Smart Grid 2017, 8, 2207-2216. [CrossRef]

287. Al-Otaibi, R.; Jin, N.; Wilcox, T.; Flach, P. Feature Construction and Calibration for Clustering Daily Load Curves from Smart-Meter Data. IEEE Trans. Ind. Inform. 2016, 12, 645-654. [CrossRef]

288. Peng, W.; Deng, Z.; Zhu, Y.; Lu, J. An analytical method for intelligent electricity use pattern with demand response. In Proceedings of the China International Conference on Electricity Distribution, CICED, Xi'an, China, 10-13 August 2016. [CrossRef]

289. Khan, I.; Huang, J.Z.; Masud, M.A.; Jiang, Q. Segmentation of factories on electricity consumption behaviors using load profile data. IEEE Access 2016, 4, 8394-8406. [CrossRef]

290. Li, R.; Li, F.; Smith, N.D. Load Characterization and Low-Order Approximation for Smart Metering Data in the Spectral Domain. IEEE Trans. Ind. Inform. 2017, 13, 976-984. [CrossRef]

291. Zhang, D.; Li, S.; Sun, M.; O'Neill, Z. An Optimal and Learning-Based Demand Response and Home Energy Management System. IEEE Trans. Smart Grid 2016, 7, 1790-1801. [CrossRef]

292. Jindal, A.; Dua, A.; Kaur, K.; Singh, M.; Kumar, N.; Mishra, S. Decision Tree and SVM-Based Data Analytics for Theft Detection in Smart Grid. IEEE Trans. Ind. Inform. 2016, 12, 1005-1016. [CrossRef]

293. Haben, S.; Singleton, C.; Grindrod, P. Analysis and clustering of residential customers energy behavioral demand using smart meter data. IEEE Trans. Smart Grid 2016, 7, 136-144. [CrossRef]

294. Munshi, A.A.; Mohamed, Y.A.R.I. Extracting and defining flexibility of residential electrical vehicle charging loads. IEEE Trans. Ind. Inform. 2018, 14, 448-461. [CrossRef]

295. Li, R.; Gu, C.; Li, F.; Shaddick, G.; Dale, M. Development of Low Voltage Network Templates-Part II: Peak Load Estimation by Clusterwise Regression. IEEE Trans. Power Syst. 2015, 30, 3045-3052. [CrossRef]

296. Wang, Y.; Chen, Q.; Kang, C.; Xia, Q.; Luo, M. Sparse and Redundant Representation-Based Smart Meter Data Compression and Pattern Extraction. IEEE Trans. Power Syst. 2017, 32, 2142-2151. [CrossRef]

297. Gopinath, R.; Kumar, M.; Joshua, C.P.C.; Srinivas, K. Energy management using non-intrusive load monitoring techniques-Stateof-the-art and future research directions. Sustain. Cities Soc. 2020, 62, 102411. [CrossRef]

298. Devlin, M.A.; Hayes, B.P. Non-Intrusive Load Monitoring and Classification of Activities of Daily Living Using Residential Smart Meter Data. IEEE Trans. Consum. Electron. 2019, 65, 339-348. [CrossRef]

299. Javaid, N.; Hafeez, G.; Iqbal, S.; Alrajeh, N.; Alabed, M.S.; Guizani, M. Energy Efficient Integration of Renewable Energy Sources in the Smart Grid for Demand Side Management. IEEE Access 2018, 6, 77077-77096. [CrossRef]

300. Kong, W.; Dong, Z.Y.; Ma, J.; Hill, D.J.; Zhao, J.; Luo, F. An Extensible Approach for Non-Intrusive Load Disaggregation with Smart Meter Data. IEEE Trans. Smart Grid 2018, 9, 3362-3372. [CrossRef] 
301. Henao, N.; Agbossou, K.; Kelouwani, S.; Dube, Y.; Fournier, M. Approach in Nonintrusive Type i Load Monitoring Using Subtractive Clustering. IEEE Trans. Smart Grid 2017, 8, 812-821. [CrossRef]

302. Chung, J.; Gillis, J.M.; Morsi, W.G. Non-intrusive load monitoring using wavelet design and co-testing of machine learning classifiers. In Proceedings of the 2016 IEEE Electrical Power and Energy Conference, EPEC 2016, Ottawa, ON, Canada, 12-14 October 2016. [CrossRef]

303. Jokar, P.; Arianpoo, N.; Leung, V.C.M. Electricity theft detection in AMI using customers' consumption patterns. IEEE Trans. Smart Grid 2016, 7, 216-226. [CrossRef]

304. Zhan, T.S.; Chen, S.J.; Kao, C.C.; Kuo, C.L.; Chen, J.L.; Lin, C.H. Non-technical loss and power blackout detection under advanced metering infrastructure using a cooperative game based inference mechanism. IET Gener. Transm. Distrib. 2016, 10, 873-882. [CrossRef]

305. Guerrero, J.I.; Monedero, I.; Biscarri, F.; Biscarri, J.; Millan, R.; Leon, C. Non-Technical Losses Reduction by Improving the Inspections Accuracy in a Power Utility. IEEE Trans. Power Syst. 2018, 33, 1209-1218. [CrossRef]

306. Yu, X.; Xue, Y. Smart Grids: A Cyber-Physical Systems Perspective. Proc. IEEE 2016, 104, 1058-1070. [CrossRef]

307. Shahinzadeh, H.; Moradi, J.; Gharehpetian, G.B.; Nafisi, H.; Abedi, M. IoT Architecture for smart grids. In Proceedings of the International Conference on Protection and Automation of Power System, IPAPS, Tehran, Iran, 8-9 January 2019; pp. 22-30. [CrossRef]

308. Diamantoulakis, P.D.; Kapinas, V.M.; Karagiannidis, G.K. Big Data Analytics for Dynamic Energy Management in Smart Grids. Big Data Res. 2015, 2, 94-101. [CrossRef]

309. Alahakoon, D.; Yu, X. Smart Electricity Meter Data Intelligence for Future Energy Systems: A Survey. IEEE Trans. Ind. Inform. 2016, 12, 425-436. [CrossRef]

310. Zhou, K.; Fu, C.; Yang, S. Big data driven smart energy management: From big data to big insights. Renew. Sustain. Energy Rev. 2016, 56, 215-225. [CrossRef]

311. Al-Musaylh, M.S.; Deo, R.C.; Adamowski, J.F.; Li, Y. Short-term electricity demand forecasting with MARS, SVR and ARIMA models using aggregated demand data in Queensland, Australia. Adv. Eng. Inform. 2018, 35, 1-16. [CrossRef]

312. Valogianni, K.; Ketter, W. Effective demand response for smart grids: Evidence from a real-world pilot. Decis. Support Syst. 2016, 91, 48-66. [CrossRef]

313. Candanedo, L.M.; Feldheim, V.; Deramaix, D. Data driven prediction models of energy use of appliances in a low-energy house. Energy Build. 2017, 140, 81-97. [CrossRef]

314. Chou, J.S.; Ngo, N.T. Smart grid data analytics framework for increasing energy savings in residential buildings. Autom. Constr. 2016, 72, 247-257. [CrossRef]

315. Naveen, P.; Ing, W.K.; Danquah, M.K.; Sidhu, A.S.; Abu-Siada, A. Cloud computing for energy management in smart gridAn application survey. In Proceedings of the IOP Conference Series: Materials Science and Engineering, Miri, Malaysia, 6-8 November 2015; Volume 121. [CrossRef]

316. Dakkak, O.; Nor, S.A.; Sajat, M.S.; Fazea, Y.; Arif, S. From grids to clouds: Recap on challenges and solutions. AIP Conf. Proc. 2018, 2016, 020040. [CrossRef]

317. Wang, Y.; Chen, Q.; Hong, T.; Kang, C. Review of Smart Meter Data Analytics: Applications, Methodologies, and Challenges. IEEE Trans. Smart Grid 2019, 10, 3125-3148. [CrossRef]

318. Lin, W.; Peng, G.; Bian, X.; Xu, S.; Chang, V.; Li, Y. Scheduling Algorithms for Heterogeneous Cloud Environment: Main Resource Load Balancing Algorithm and Time Balancing Algorithm. J. Grid Comput. 2019, 17, 699-726. [CrossRef]

319. Bera, S.; Misra, S.; Rodrigues, J.J.P.C. IEEE Transactions on Parallel and Distributed Systems Cloud Computing Applications for Smart Grid: A Survey. 2015. Available online: http://www.ieee.org/publications_standards/publications/rights/index.html (accessed on 16 August 2021). 